\title{
Pleurotus spp. Cultivation on Different Agri-Food By-Products: Example of Biotechnological Application
}

\author{
Mena Ritota *(1) and Pamela Manzi $\mathbb{B}$ \\ Consiglio per la ricerca in agricoltura e l'analisi dell'economia agraria (CREA) Centro di ricerca Alimenti e \\ Nutrizione Via Ardeatina 546, 00178 Rome, Italy \\ * Correspondence: mena.ritota@crea.gov.it; Tel.: +39-06-51-494-1
}

Received: 30 July 2019; Accepted: 10 September 2019; Published: 16 September 2019

check for updates

\begin{abstract}
Agri-food industry generally produces huge volumes of wastes all over the world, and their disposal is a threat to the environment and public health. The chemical composition of most of these wastes make them be defined as lignocellulosic materials, so they could be a suitable substrate for solid-state fermentation process operated by mushrooms. White-rot fungi are well known for their degradation ability of lignocellulosic material, and many scientific works reported the use of different substrates for their production. Biotechnological treatments of agri-food wastes by mushrooms could be considered an eco-friendly solution to reuse and valorize them, besides to reduce their environmental impact. In this way, wastes would be transformed into new resources to produce added-value food products, besides representing an economic return for the same industries. The aim of this review is to provide an overview of the recent literature concerning the use of different agri-food residues as growth substrates for Pleurotus spp. cultivation, with attention to their effects on the growth and chemical composition of the cultivated mushrooms.
\end{abstract}

Keywords: Pleurotus; field-based residues; processing-based residues; food waste; chemical composition

\section{Introduction}

One of the main problems to be faced all over the world is the disposal of both the large quantity of agro-industrial wastes and the residues deriving from the livestock activities [1]. According to the Food Sustainability Index - a global study on nutrition, sustainable agriculture and food waste, which collects data from 67 countries around the world - every year the world population on average wastes $37 \mathrm{~kg}$ of food per person [2]. Generally, high-income countries produce a larger amount of food waste compared to low-income countries (see Figure 1).

In 2012 the European Union alone generated approximately 88 million tons of food wastes, 9 million tons arising from primary production and 17 million tons coming from processing sector [3]. This value is intended to significantly increase, and it is expected to rise to about 126 million tons by 2020 [4]. Therefore, different strategies have been already adopted [5] to manage these existing accumulated food wastes. Some examples are the industrial reuse of food wastes in the biomaterials production and energy generation in the form of biogas [6], though anaerobic digestion and anaerobic co-digestion of food waste seem to be among the best waste management strategies since they can be considered a renewable energy source with low emissions [6]. 


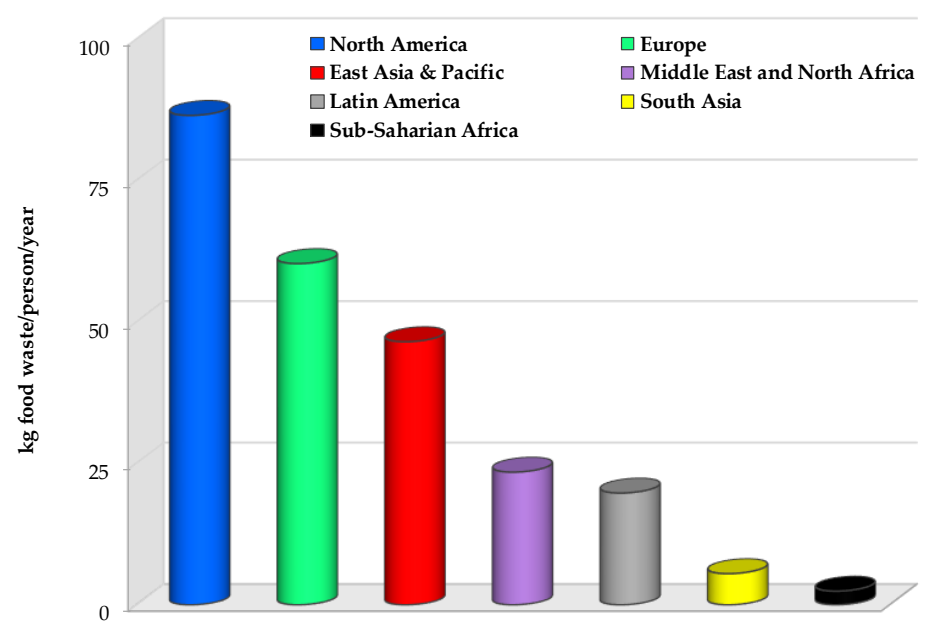

Figure 1. World food waste per capita per year (modified from [2]).

Generally, agro-industrial wastes are inappropriately disposed [7], with the consequence of threatening the environment and public health. Agro-industrial wastes are generally characterized by high biological oxygen demand (BOD) and chemical oxygen demand (COD) [5], and they are also easily susceptible to bacterial contamination due to the high water content [5]. Therefore their disposal is difficult. Fortunately, agro-industrial wastes still have high nutritional prospective [7], because they are mainly composed of sugars, fibers, proteins, and minerals [8]. Due to their composition, currently there is a great interest in their reuse [8] so that they can be also categorized as agro-industrial by-products [7].

The presence of carbon sources, nutrients and moisture in agro-industrial wastes provides suitable conditions for the development of microorganisms [8], opening the gateway of many applications in the field of solid-state fermentation (SSF) process.

Solid-state fermentation is defined as the fermentation operated by microorganism grown on solid particles in absence (or near absence) of free water [9]. The substrate of SFF is a solid material which acts both as physical support and source of nutrients, and it must possess enough moisture to support the growth and metabolism of microorganism, such as fungi, yeasts, and bacteria [9]. Different substrates can be employed, such as solid materials originating from agriculture, food, paper, textiles, detergent, and animal feed industries [7]. SSF has found large applications in the recent years, such as production of enzymes and other important biomolecules, bio pulping processes, and bioreactors design [10], or to produce added-value products using agro-industrial wastes as solid substrates [7,11].

Many of the agro-industrial residues are mainly composed of cellulose, hemicellulose, and lignin, being called lignocellulosic materials [8]. These characteristics make them a suitable substrate for solid-state fermentation process operated by mushrooms, thanks to mushrooms complex enzymes system able to degrade lignocellulosic materials.

Lignocellulosic degradation is a complex process, which requires a series of hydrolytic and oxidative enzymes (Figure 2): the first is responsible for cellulose and hemicellulose degradation, while the latter operates lignin depolymerization [12-15].

The degradation mechanisms of lignocellulosic materials by white- and brown-rot fungi are widely described in the literature [16], while little is known about lignocellulose degradation by soft-rot fungi [16]. 


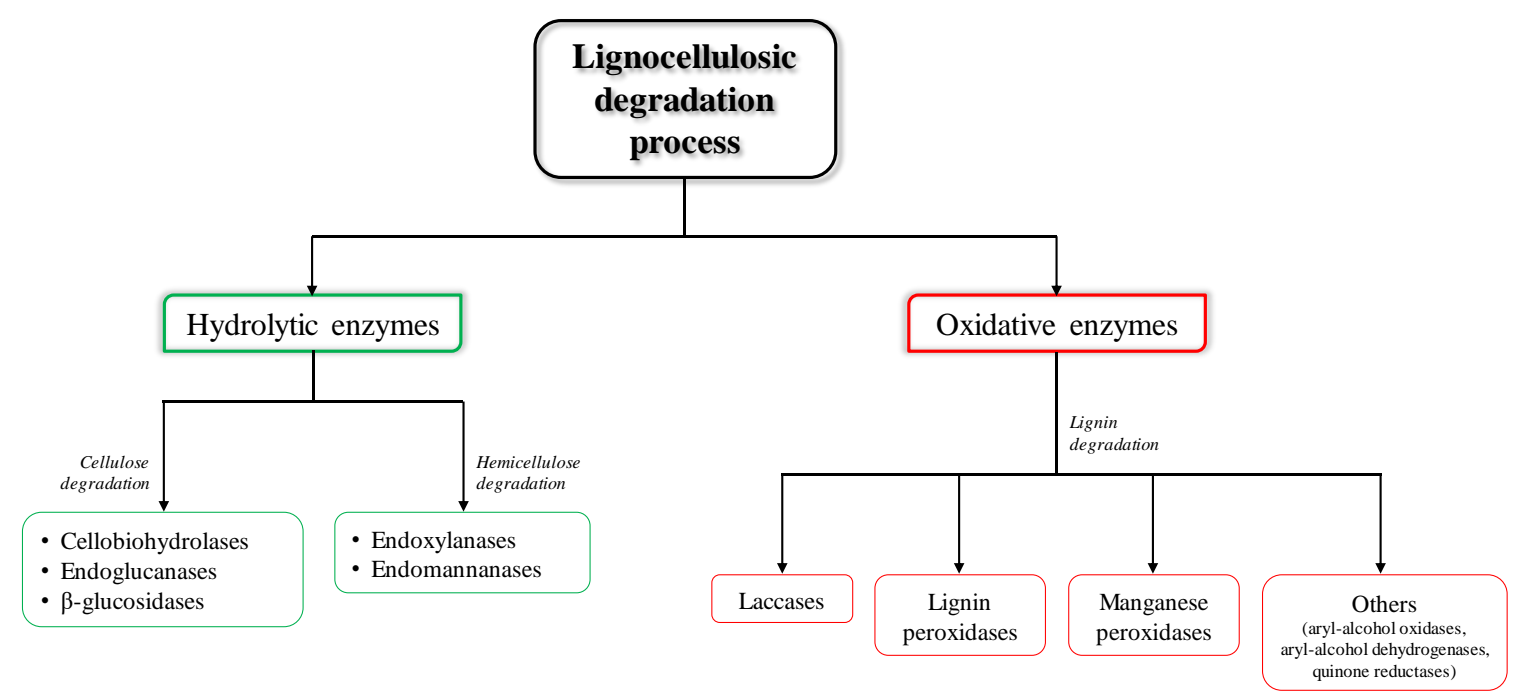

Figure 2. Scheme of the main enzymes involved in the lignocellulosic degradation process.

A lot of edible mushrooms have also proven to be able to degrade lignocellulosic materials $[11,17,18]$. Since edible mushrooms are widespread throughout the world [19], the ligninolytic enzymes system of edible mushrooms may be used for the recycling of a lot of worldwide agro-industrial wastes, depending on the local availability of agricultural and food industry residues. In this way, the environmentally sound management of wastes would be combined with the generation of food products with added value.

In recent years, mushrooms production has increased worldwide [20], so much so that it almost doubled from 2005 to 2017 (Figure 3).

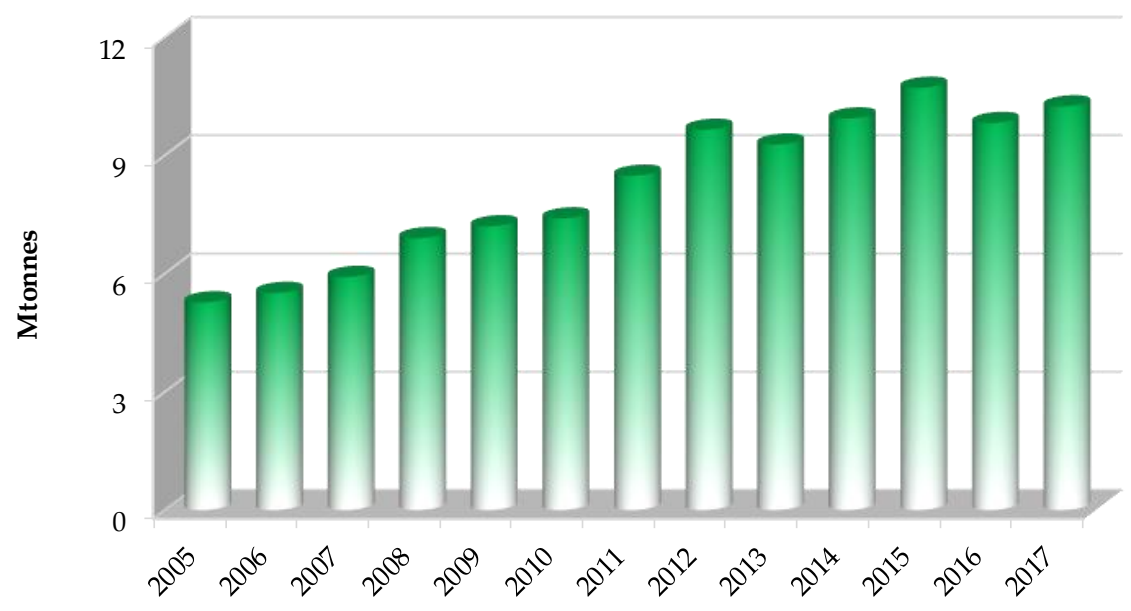

Figure 3. Evolution of mushrooms worldwide production (modified from [20]).

Mushrooms are appreciated not only for the texture and flavor but also for their chemical and nutritional properties [21]. Mushrooms can be considered healthy foods, thanks to their mineral, dietary fiber, and protein contents, and because they are poor in calories and energy [22]. Some species also showed good biological value of proteins [22-24]. Carbohydrates approximately represent 50\% of dry matter [25]. Homopolysaccharides, particularly glucans, are indeed the most responsible for mushrooms biological activities [26], and recent studies also revealed the therapeutic properties of mushrooms heteropolysaccharides [27]. Mushrooms are also rich in bioactive compounds [28-30], thus possessing radical scavenging activity and exerting antibacterial effects [31-33].

Pleurotus ostreatus, a white-rot fungus, is one of the most worldwide cultivated species, together with Agaricus bisporus and Lentinula edodes [11]. Agaricus spp. are litter-decomposing fungi (LDFs), 
with an overall lignin degradation rate lower than that of white-rot fungi [18]. These mushrooms are less interesting from a nutritional point of view, due to their negligible beta-glucans content, unlike some species of the Pleurotus genus [34]. Also Lentinula edodes, a white-rot fungus, has been proven to be highly promising in selectively degrading lignin [11], but it is widespread especially in Japan and China, even if its cultivation is now increasing also in Europe.

Pleurotus spp. are selective degraders, degrading lignin and hemicellulose rather than cellulose, which in this way remains exposed and can be utilized by ruminants [17]. Furthermore, Pleurotus spp. have the advantage of very simple cultivation compared to that of the most commonly cultivated mushroom, A. bisporus [17]: actually, non-composted, chopped and water-soaked straw is sufficient for Pleurotus cultivation [11].

Thanks to their biodegradation capability, nutritional value, and spread in Europe, Pleurotus spp. could be a useful tool not only to reduce the environmental impact of agri-food wastes but also to transform them into new resources for the simultaneous production of edible food items with high added value.

The aim of this review is to provide an overview of the recent literature focused on the use of different agri-food residues as growth substrates for Pleurotus spp. cultivation, known for its selective capacity in lignin degradation, with particular attention focused on field-based and processing-based residues, whose disposal could cause environmental pollution. Data regarding production parameters for mushrooms cultivation are provided, with particular attention to biological efficiency (BE), calculated as the percentage ratio of fresh mushrooms weight over the dry weight of the substrate. Moreover, the effects of different substrates on the proximate composition of mushrooms are also evaluated, with attention to mushrooms nutritional and functional compounds which can be affected by changes as a result of the food waste characteristics.

\section{Pleurotus spp. Cultivation on Field-Based Residues}

Different field-based residues are produced in large volumes all over the world: according to Lal [35], from 1991 to 2001 there was an increase in the world crop residue production from 3448 to $375810^{6} \mathrm{Mg}$. Recently Cherubin, et al. [36] observed a further increase, ranging between 3331 and 5010 $10^{6} \mathrm{Mg}$, from 2003 to 2013.

All these residues are generally left to rot in the field or are disposed of through burning [37]. In some cases they can also be involved in the production of livestock feed [38], but such use is limited due to the presence of high contents of non-nutritive compounds (such as lignin and silica) and/or anti-nutritional factors (tannins), which can interfere with the normal digestion, and consequent absorption, of the animal feed [39]. A biotechnological pretreatment, such as the solid-state fermentation operated by mushrooms, could be a useful tool to improve the quality of agricultural residues and make them more suitable in the utilization in livestock feed. Recently, Nasehi, et al. [40] evaluated the effect of $P$. florida solid-state fermentation on the nutritive value of some agricultural wastes (rice straw, wheat straw, barley straw, soybean straw, canola straw, pea straw, and rice husk). These agro-food residues, in fact, cannot be utilized for ruminant nutrition due to their high lignin content, but fungal pretreatment of these crop residues could be a suitable approach to obtain biological delignification of agro-food residues. The authors observed a significant increase in the protein and ash contents in all treatments of the examined agro-food residues, and a decrease in dry matter, organic matter and neutral detergent fiber after all substrates fermentation. However, the authors did not evaluate any modification in $P$. florida composition or nutritive value.

Fortunately, agricultural by-products are rich in lignocellulose, hence they could be potentially suitable substrates for oyster mushrooms cultivation. Tables 1 and 2 reports the main results regarding the cultivation of Pleurotus spp. on different field-based residues, such as cereals straw, corn stover, grass residues, and sunflower residues. 
Table 1. Chemical composition ( $100 \mathrm{~g}^{-1} \mathrm{dw}$ ) of some Pleurotus spp. species grown on different field-based residues.

\begin{tabular}{|c|c|c|c|c|c|c|c|}
\hline Species & Substrate & Protein $^{a}$ & Fat $^{a}$ & Crude Fiber & Carbohydrates & Ash $^{a}$ & References \\
\hline P. eous & Soybean straw & 21.37 & 2.60 & $9.00^{x}$ & $50.50^{y}$ & 6.50 & {$[41]^{\S}$} \\
\hline P. eous & Paddy straw & 20.56 & 2.40 & $8.00^{\mathrm{x}}$ & $48.00 \mathrm{y}$ & 6.25 & {$[41]^{\S}$} \\
\hline P. eous & Sunflower stalk & 19.19 & 2.20 & $7.92^{x}$ & $52.00 \mathrm{y}$ & 5.25 & {$[41]^{\S}$} \\
\hline P. eous & Wheat straw & 19.48 & 2.62 & $7.75^{x}$ & $50.20^{y}$ & 6.00 & {$[41]^{\S}$} \\
\hline P. eous & Jowar straw & 19.17 & 2.10 & $7.45^{x}$ & $49.00^{\mathrm{y}}$ & 6.40 & {$[41]^{\S}$} \\
\hline P. eous & Bajra straw & 18.66 & 2.10 & $7.45^{x}$ & $49.00^{\mathrm{y}}$ & 6.40 & {$[41]^{\S}$} \\
\hline P.eous & Tur stalk straw & 18.66 & 2.30 & $7.30^{x}$ & $51.40^{\mathrm{y}}$ & 5.50 & {$[41]^{\S}$} \\
\hline P. ostreatus & Pine needles & 22.74 & 2.44 & $13.68^{\mathrm{a}}$ & $75.88^{z}$ & 7.50 & {$[42]$} \\
\hline P. ostreatus & Wheat straw & 14.64 & 2.56 & $19.07^{\mathrm{a}}$ & $74.41^{\mathrm{z}}$ & 8.56 & {$[42]$} \\
\hline P. ostreatus & Wheat straw & 14.41 & 2.20 & $12.08^{\mathrm{a}}$ & $40.96^{\mathrm{a}}$ & 8.30 & {$[43]^{\S}$} \\
\hline P. sajor-caju & Wheat straw $+20 \%$ mahua cake detoxified with methanol & 34.76 & 1.76 & n.r. & $30.66^{¥}$ & 8.23 & {$[44]$} \\
\hline P. sajor-caju & Wheat straw $+10 \%$ mahua cake detoxified with methanol & 34.16 & 1.76 & n.r. & $30.50^{¥}$ & 8.09 & [44] \\
\hline P. sajor-caju & Wheat straw $+10 \%$ mahua cake detoxified with cold water & 33.46 & 1.78 & n.r. & $31.43^{¥}$ & 7.98 & [44] \\
\hline P. sajor-caju & Wheat straw $+10 \%$ mahua cake & 33.00 & 1.76 & n.r. & $31.86^{¥}$ & 8.19 & [44] \\
\hline P. sajor-caju & Wheat straw $+30 \%$ mahua cake detoxified with methanol & 32.43 & 1.77 & n.r. & $29.33^{¥}$ & 8.00 & [44] \\
\hline P. sajor-caju & Wheat straw $+20 \%$ mahua cake detoxified with cold water & 31.23 & 1.75 & n.r. & $29.66^{¥}$ & 7.92 & [44] \\
\hline P. sajor-caju & Wheat straw $+20 \%$ mahua cake & 31.00 & 1.80 & n.r. & $31.90^{¥}$ & 8.04 & [44] \\
\hline P. sajor-caju & Wheat straw $+30 \%$ mahua cake detoxified with cold water & 30.83 & 1.78 & n.r. & $28.60^{¥}$ & 8.03 & [44] \\
\hline P. sajor-caju & Wheat straw $+40 \%$ mahua cake detoxified with methanol & 30.33 & 1.75 & n.r. & $28.83 \stackrel{7}{¥}$ & 7.99 & [44] \\
\hline P. sajor-caju & Wheat straw & 29.36 & 2.07 & n.r. & $32.16^{¥}$ & 8.05 & [44] \\
\hline P. sajor-caju & Wheat straw $+40 \%$ mahua cake detoxified with cold water & 29.16 & 1.76 & n.r. & $28.83 \stackrel{7}{¥}$ & 8.10 & [44] \\
\hline P. sajor-caju & Wheat straw $+40 \%$ mahua cake & 28.16 & 1.81 & n.r. & $31.03^{¥}$ & 8.02 & [44] \\
\hline P. sajor-caju & Wheat straw $+30 \%$ mahua cake & 27,43 & 1.83 & n.r. & $31.93^{¥}$ & 8.14 & {$[44]$} \\
\hline P. sapidus & Soybean straw & 18,75 & 2.10 & $7.50^{x}$ & $24.95^{\mathrm{y}}$ & 7.00 & {$[45]^{\S}$} \\
\hline P. sapidus & Paddy straw & 16,40 & 1.60 & $8.00^{x}$ & $45.65^{\mathrm{y}}$ & 6.35 & {$[45]^{\S}$} \\
\hline P. sapidus & Jowar straw & 15.98 & 2.00 & $6.75^{x}$ & $50.60 \mathrm{y}$ & 5.85 & {$[45]^{\S}$} \\
\hline P. sapidus & Bajra straw & 15.49 & 1.80 & $6.00^{x}$ & $47.00^{y}$ & 5.40 & {$[45]^{\S}$} \\
\hline P. sapidus & Tur stalk straw & 15.17 & 1.50 & $7.65^{x}$ & $44.25^{\mathrm{y}}$ & 6.50 & {$[45]^{\S}$} \\
\hline P. sapidus & Wheat straw & 14.96 & 2.60 & $6.80^{x}$ & $52.00^{y}$ & 5.63 & {$[45]^{\S}$} \\
\hline P. sapidus & Sunflower stalk & 14.10 & 2.40 & $7.32^{x}$ & $48.50^{\mathrm{y}}$ & 6.20 & {$[45]^{\S}$} \\
\hline
\end{tabular}

of Maynard [46], ${ }^{y}$ total carbohydrates determined by the phenol sulphuric acid method [47], ${ }^{\mathrm{z}}$ total carbohydrates determined by difference. 
Table 2. Biological efficiency (BE \%) of some Pleurotus spp. species cultivation on different field-based residues.

\begin{tabular}{|c|c|c|c|}
\hline Species & Substrate & BE & References \\
\hline P. citrinopileatus & Pea pod:paddy straw $(30: 70)$ & 94.3 & [48] \\
\hline P. citrinopileatus & Brassica straw:paddy straw (30:70) & 92.3 & [48] \\
\hline P. citrinopileatus & Cauliflower leaves:paddy straw (30:70) & 91.0 & [48] \\
\hline P. citrinopileatus & Brassica straw:paddy straw $(20: 80)$ & 90.8 & [48] \\
\hline P. citrinopileatus & Cauliflower leaves:paddy straw (20:80) & 90.8 & [48] \\
\hline P. citrinopileatus & Paddy straw & 90.0 & [48] \\
\hline P. citrinopileatus & Pea pod:paddy straw $(20: 80)$ & 90.0 & [48] \\
\hline P. citrinopileatus & Peapod & 0 & [48] \\
\hline P. citrinopileatus & Cauliflower leaves & 0 & [48] \\
\hline P. eous & Soybean straw & 82.0 & [41] \\
\hline P. eous & Paddy straw & 79.8 & [41] \\
\hline P. eous & Wheat straw & 75.1 & [41] \\
\hline P. eous & Jowar straw & 73.2 & [41] \\
\hline P. eous & Bajra straw & 71.6 & [41] \\
\hline P. eous & Tur stalk straw & 68.0 & [41] \\
\hline P. eous & Sunflower stalk & 61.5 & [41] \\
\hline P. eryngii & Wheat straw & 87.5 & [49] \\
\hline P. eryngii & Wheat straw & 57.3 & [50] \\
\hline P. eryngii & Wheat straw & 48.2 & [51] \\
\hline P. eryngii & Wheat straw & 38.4 & {$[50]$} \\
\hline P. eryngii & Rice straw & 46.0 & [51] \\
\hline P. florida & Paddy straw $+4 \%$ CaSO 4 & 95.5 & [52] \\
\hline P. florida & Paddy straw $+6 \% \mathrm{MgSO} 4$ & 85.2 & [52] \\
\hline P. florida & Paddy straw $+0.4 \%$ FeSO 4 & 51.5 & [52] \\
\hline P. florida & Paddy straw $+0.2 \% \mathrm{ZnSO} 4$ & 37.8 & [52] \\
\hline P. ostreatus & Wheat straw & 114.9 & [43] \\
\hline P. ostreatus & Wheat straw & 106.7 & [50] \\
\hline P. ostreatus & Wheat straw $+5 \%$ wheat bran & 92.5 & [53] \\
\hline P. ostreatus & Paddy straw & 82.7 & [54] \\
\hline P. ostreatus & Wheat straw & 79.7 & [50] \\
\hline P. ostreatus & Wheat straw & 70.2 & [49] \\
\hline P. ostreatus & Wheat straw & 67.8 & [50] \\
\hline P. ostreatus & Wheat straw & 60.3 & [54] \\
\hline P. ostreatus & Deenanath grass & 59.6 & [54] \\
\hline P. ostreatus & Banana leaves & 58.6 & [54] \\
\hline P. ostreatus & Wheat straw & 57.4 & [55] \\
\hline P. ostreatus & Wheat straw & 52.6 & [42] \\
\hline P. ostreatus & Maize stover & 41.8 & [55] \\
\hline P. ostreatus & Maize stalks and leaves & 27.0 & [54] \\
\hline P. pulmonarius & Wheat straw & 99.7 & [49] \\
\hline P. sajor-caju & Wheat straw $+5 \%$ wheat bran & 96.5 & [53] \\
\hline P. sajor-caju & Cotton stalks + wheat straw & 79.6 & {$[56] \sim$} \\
\hline P. sajor-caju & $\begin{array}{c}\text { Cotton stalks+groundnut haulms+soybean straw+pigeon pea stalks and } \\
\text { leaves+wheat straw }\end{array}$ & 75.0 & [56] \\
\hline P. sajor-caju & Pigeon pea stalks and leaves+wheat straw & 73.6 & {$[56] \sim$} \\
\hline P. sajor-caju & Cotton stalks+pigeon pea stalks and leaves & 71.3 & {$[56] \sim$} \\
\hline P. sajor-caju & Cotton stalks+pigeon pea stalks and leaves+wheat straw & 70.3 & {$[56] \sim$} \\
\hline P. sajor-caju & Soybean straw+wheat straw & 66.8 & {$[56] \sim$} \\
\hline P. sajor-caju & Cotton stalks+soybean straw & 66.1 & {$[56] \sim$} \\
\hline P. sajor-caju & Cotton stalks+groundnut haulms+wheat straw & 65.7 & {$[56] \sim$} \\
\hline P. sajor-caju & Cotton stalks+soybean straw+wheat straw & 64.1 & {$[56] \sim$} \\
\hline P. sajor-caju & Groundnut haulms+wheat straw & 63.6 & {$[56] \sim$} \\
\hline P. sajor-caju & Cotton stalks+soybean straw+pigeon pea stalks and leaves & 63.4 & {$[56] \sim$} \\
\hline P. sajor-caju & Groundnut haulms+soybean straw+pigeon pea stalks and leaves + wheat straw & 61.5 & {$[56] \sim$} \\
\hline P. sajor-caju & Cotton stalks+groundnut haulms & 59.7 & {$[56] \sim$} \\
\hline P. sajor-caju & Cotton stalks+groundnut haulms+soybean straw+wheat straw & 59.1 & [56] \\
\hline P. sajor-caju & Cotton stalks+groundnut haulms+soybean straw+pigeon pea stalks and leaves & 58.3 & [56] \\
\hline P. sajor-caju & Groundnut haulms+pigeon pea stalks and leaves & 55.7 & {$[56] \sim$} \\
\hline P. sajor-caju & Cotton stalks+groundnut haulms+pigeon pea stalks and leaves & 53.3 & [56] \\
\hline P. sajor-caju & Groundnut haulms+soybean straw+wheat straw & 51.3 & [56] \\
\hline P. sajor-caju & Cotton stalks & 51.1 & [56] \\
\hline P. sajor-caju & Cotton stalks+groundnut haulms+soybean straw & 48.7 & {$[56] \sim$} \\
\hline P. sajor-caju & Pigeon pea stalks and leaves & 46.3 & [56] \\
\hline
\end{tabular}


Table 2. Cont.

\begin{tabular}{|c|c|c|c|}
\hline Species & Substrate & BE & References \\
\hline P. sajor-caju & Soybean straw+pigeon pea stalks and leaves & 45.7 & [56] \\
\hline P. sajor-caju & Soybean straw+pigeon pea stalks and leaves+wheat straw & 45.1 & [56] \\
\hline P. sajor-caju & Wheat straw & 44.7 & {$[56] \sim$} \\
\hline P. sajor-caju & Groundnut haulms+soybean straw+pigeon pea stalks and leaves & 39.5 & [56] \\
\hline P. sajor-caju & Groundnut haulms & 36.5 & {$[56] \sim$} \\
\hline P. sajor-caju & Groundnut haulms+soybean straw & 33.3 & [56] \\
\hline P. sajor-caju & Soybean straw & 25.8 & [56] \\
\hline P. sapidus & Soybean straw & 72.9 & [45] \\
\hline P. sapidus & Paddy straw & 64.7 & [45] \\
\hline P. sapidus & Wheat straw & 62.2 & [45] \\
\hline P. sapidus & Jowar straw & 50.3 & [45] \\
\hline P. sapidus & Tur stalk straw & 48.4 & [45] \\
\hline P. sapidus & Wheat straw $+5 \%$ wheat bran & 47.9 & [53] \\
\hline P. sapidus & Bajra straw & 46.7 & [45] \\
\hline P. sapidus & Sunflower stalk & 45.9 & [45] \\
\hline
\end{tabular}

$\sim$ Data modified from relevant references.

Cereal straws can be considered an agriculture by-product of cereal threshing. These crop residues are produced in large volumes all over the world, especially in those regions with expanding agricultural production. Chopped wheat straw is generally the main component of the growth substrate for Pleurotus spp. cultivation [11], but the supplementation with protein-rich materials is often carried out in order to enhance the yield.

Gupta, et al. [44], for example, evaluated the effect of the supplementation of wheat straw with mahua cake (MC), an important by-product of the Madhuca indica, an Indian tropical tree, on the yield and chemical composition of $P$. sajor-caju. This residue is rich in sugars and proteins, but it also contains toxic compounds, such as saponins. Therefore, the authors evaluated the development of the fruit bodies of P. sajor-caju on mahua cake as is, on MC detoxified with cold water (CW DMC) and on MC detoxified with methanol (DMC). The wheat straw supplementation with MC increased mushroom yields with increasing the cake addition, up to a certain level $(10 \%$ for MC as-is and $10 \%$ for CW DMC, 20\% for DMC). MC detoxification significantly improved the mushroom yield (highest value of $1024.8 \mathrm{~g} \mathrm{~kg}^{-1}$ dry substrate), reaching an average increase of $75 \%$ in the yield compared to the control (wheat straw), the authors ascribed this effect to the potential inhibitory effect of the cake saponins to the growth of mushroom. The substrates with the highest yield also gave the highest protein contents $(\mathrm{N} \times 4.38)$ in the fruit bodies (Table 1$)$.

Jeznabadi, et al. [57], instead, evaluated the effects of different sources of Iranian agricultural wastes on the production parameters and protein content in the cultivation of P. eryngii. Wheat straw, wood chips, sawdust, sugar beet pulp, barley straw, and maize stem residues were used as basal substrates, whereas wheat bran, rice bran, soybean powder, and their combinations were used as supplement. Barley straw supplemented with rice bran gave the highest mushroom yield $(83.5 \mathrm{~g}$

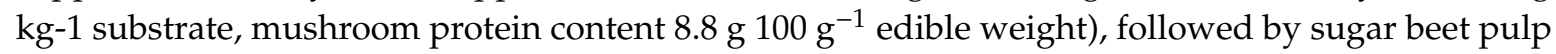

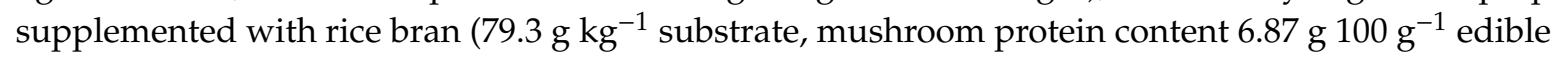
weight), whereas the substrate with the worst performance was sawdust supplemented with rice

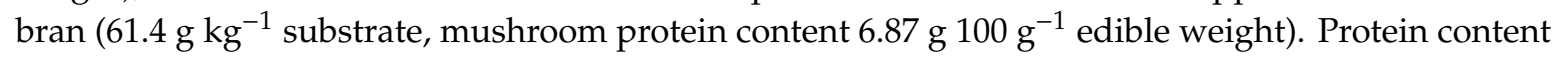
was differently affected by the various substrates, ranging between $4.64 \%$ (barley straw + wheat bran and wood chips + soybean powder + rice bran treatments) and $13.66 \%$ (wheat straw + wheat bran + soybean powder treatment). The results of this work show that mushroom proteins did not often increase with the increase of yield, and they were not in agreement with Gupta, et al. [44]. The results observed by Jeznabadi, et al. [57] are probably due to the differences in the characteristics (i.e., $\mathrm{C} / \mathrm{N}$ ratio and/or chemical composition) of the substrates, while Gupta, et al. [44] evaluated the same substrate in different concentrations.

Shevale and Deshmukh [48] observed better results, in terms of total yield and biological efficiency, when paddy straw was used in combination with other vegetable wastes (brassica straw, peapod, and cauliflower leaves) than paddy straw alone in the cultivation of P. citrinopileatus. In particular, the 
yield and BE were the highest in the growth substrates of $70 \%$ paddy straw and $30 \%$ other agri-wastes. Furthermore, the addition of paddy straw to pea pod and cauliflower leaves is necessary in order to allow the mushrooms growth, which was prevented on pea pod and cauliflower leaves alone, probably due to the water excess of the growth substrate.

Corn stover is another agricultural by-product produced in large quantity all over the world. Generally, it is used by several companies to produce bedding, insulating materials, particleboard, paper, chemicals, and bioethanol [58]. However, its high lignocellulosic content and its relatively large availability make corn stover a potential cheap substrate for mushroom cultivation. Among the different agricultural wastes evaluated by Khan, et al. [59] in the cultivation of various species of Pleurotus, corn stover revealed the growth substrate with the lowest yield, while the cotton waste gave the highest yield value.

Residues originating from various grasses can be considered other examples of crop-based residues which can be recovered and upgraded to higher-value products [11]. In the study of Mumtaz, et al. [60] lemon grass tested as growth substrate for P. pulmonarius cultivation gave higher yield in combination with other agricultural wastes than alone (yield value of $264.8 \mathrm{~g}$ compared to $385.2 \mathrm{~g}$ obtained with the substrate composed of lemongrass and cotton waste in the ratio 1:1). Also Vieira and Andrade [61] evaluated grass residues, besides sugarcane straw and wheat straw, as growth substrates for the cultivation of Pleurotus ostreatus. Brizantha grass (Brachiaria brizantha), a native grass of tropical regions and particularly popular among cattle farmers in Kenya, showed the highest mushroom yield (28.5\%), followed by decumbens grass (Brachiaria decumbes), a native grass of tropical and subtropical regions of Asia, Africa, Australia, southern Europe, and the Americas. Furthermore, brizantha grass showed the highest biological efficiency ( $\mathrm{BE}=124.0 \%$ ), followed by sugarcane straw, decumbens grass, and wheat straw $(103.7 \%, 96.9 \%$, and $86.4 \%$, respectively). Moreover, the authors obtained better performances in terms of yields and BEs by addition of wheat bran used as nitrogen supplementation to the substrates.

In the evaluation of different agro-substrates for mushroom growth, Hossain [54] also tested deenanath grass (Pennisetum pedicellatum), an indigenous grass of Ethiopia, in the cultivation of $P$. ostreatus: the substrate gave a yield of $596 \mathrm{~g} \mathrm{~kg}^{-1}$ dry substrate and a biological efficiency of $59.6 \%$, while the best performances were observed with paddy straw (yield $827 \mathrm{~g} \mathrm{~kg}^{-1}$ dry substrate and BE $82.7 \%)$.

Sunflower cultivation has increased in many countries in the last years: it is a good source of proteins and edible oils, and its residues, when left in the soil after harvesting, provide nutrients for and help to control weeds in the succeeding crop [62]. However, some studies reported an allelopathic influence exercised by sunflower [63], so much so that many farmers have begun to observe a reduction in the yields of crops grown in association with, or in succession to, sunflower. Therefore, it has been hypothesized that sunflower residues left in the field release phytotoxins into the soil, thus affecting the growth and yield of crops grown in rotation with sunflower [62]. For these reasons, alternative use of sunflower residues would be desirable.

Telang et al. [41,45] evaluated the yield and chemical composition of P. eous and P. sapidus cultivated on different agro wastes, among which sunflower stalk. The results showed the same trend in both mushrooms: soybean straw gave the highest biological efficiency $(82.0 \%$ and $72.9 \%$, in P. eous and P. sapidus, respectively), while the lowest value of BE was observed on sunflower stalk $(61.5 \%$ and $45.9 \%$, in P. eous and P. sapidus, respectively). At the same time, in P. eous. sunflower stalk showed the highest carbohydrate $(52.00 \%)$ and moisture contents $(90.23 \%)$, as well as the lowest ash value $(5.25 \%)$. However, further studies are needed to evaluate the real use of sunflower residues as a growth substrate for mushroom cultivation, due to the possible presence of sunflower phytotoxins.

\section{Pleurotus spp. Cultivation on Processing-Based Residues}

The food industry produces large amounts of residues all over the world: this not only represents a great loss of valuable materials, but also raises serious management problems, both from economic and environmental point of view. Fortunately, many agri-food industry residues can be potentially be 
reused into other production systems (biorefineries, livestock feeding, fertilization, and others [4] or can be used to produce value-added products [5].

Food industry residues generally contain a large amount of lignocellulosic material (except animal-derived food wastes), so they could represent good substrates for mushroom growth. In this way, the solid-state fermentation process represents a useful process to convert food industry residues into renewable resources able to produce a large variety of value-added compounds [8]. Many scientific works reported the use of different food industry residues (such as residues from oil-olive, coffee, beer, wine, hazelnut, sugarcane, or sugar beet industry) for the cultivation of edible mushrooms, and the relevant main results regarding the cultivation of Pleurotus spp. are reported in Tables 3 and 4.

Table 3. Chemical composition ( $100 \mathrm{~g}^{-1} \mathrm{dw}$ ) of some Pleurotus spp. species grown on different processing-based residues.

\begin{tabular}{|c|c|c|c|c|c|c|c|}
\hline Species & Substrate & Protein $^{a}$ & Fat $^{a}$ & $\begin{array}{l}\text { Crude } \\
\text { Fiber }\end{array}$ & Carbohydrates & Ash $^{a}$ & References \\
\hline P. ostreatus & Almond and walnut shells (1:1) & 31.36 & 2.49 & $13.00^{\mathrm{a}}$ & $56.64^{\mathrm{z}}$ & 9.86 & [42] \\
\hline P. ostreatus & Extracted olive-press cake & 21.41 & 1.64 & $13.68^{\mathrm{a}}$ & $70.21^{\mathrm{z}}$ & 6.98 & {$[42]$} \\
\hline P. ostreatus & Corncob & 20.81 & 2.67 & $29.75^{\text {a }}$ & $30.78^{z}$ & 7.10 & {$[37]^{\S}$} \\
\hline P. ostreatus & $\begin{array}{l}\text { Olive mill by-products (leaves and } \\
\text { two-phase olive mill waste } 1: 1 \text { ) }\end{array}$ & 19.74 & 2.72 & $12.50^{\mathrm{a}}$ & $68.28^{z}$ & 9.48 & [42] \\
\hline P. ostreatus & Sugarcane bagasse & 19.01 & 2.00 & $29.25^{a}$ & $34.94^{\mathrm{z}}$ & 6.68 & {$[37]^{\S}$} \\
\hline P. ostreatus & Sawdust:corncob (50:50) & 17.98 & 1.80 & $28.25^{a}$ & $37.50^{\mathrm{z}}$ & 6.80 & {$[37]^{\S}$} \\
\hline P. ostreatus & Sawdust:sugarcane bagasse (50:50) & 16.94 & 2.50 & $28.75^{\mathrm{a}}$ & $37.88^{z}$ & 6.70 & {$[37]^{\S}$} \\
\hline P. ostreatus & Date palm tree leaves & 16.13 & 3.41 & $19.89^{\mathrm{a}}$ & $72.77^{\mathrm{z}}$ & 7.83 & [42] \\
\hline P. ostreatus & Beech sawdust & 16.06 & 3.46 & $15.78^{\mathrm{a}}$ & $73.56^{\mathrm{z}}$ & 6.21 & [42] \\
\hline P. ostreatus & Grape marc + cotton gin trash $(1: 1)$ & 15.99 & 2.81 & $24.26^{\mathrm{a}}$ & $72.95^{\mathrm{z}}$ & 8.43 & [42] \\
\hline P. ostreatus & Corncobs & 15.41 & 3.37 & $13.76^{\mathrm{a}}$ & $73.37^{z}$ & 8.02 & {$[42]$} \\
\hline P. ostreatus & Sawdust:sugarcane bagasse $(80: 20)$ & 15.33 & 2.78 & $24.02^{\mathrm{a}}$ & $44.97^{\mathrm{z}}$ & 6.35 & {$[37]^{\S}$} \\
\hline P. ostreatus & Trash/bagasse mixture & 14.89 & 1.85 & $12.65^{\mathrm{a}}$ & $40.41^{\mathrm{a}}$ & 6.64 & {$[43]^{\S}$} \\
\hline P. ostreatus & Sawdust:corncob $(80: 20)$ & 14.64 & 2.08 & $23.04^{\mathrm{a}}$ & $47.62^{z}$ & 6.37 & {$[37]^{\S}$} \\
\hline P. ostreatus & Sugar cane trash & 13.79 & 1.79 & $12.39^{a}$ & $41.20^{\mathrm{a}}$ & 7.82 & {$[43]^{\S}$} \\
\hline P. ostreatus & Sawdust & 13.68 & 1.32 & $22.00^{\mathrm{a}}$ & $51.26^{\mathrm{z}}$ & 5.90 & {$[37]^{\S}$} \\
\hline P. ostreatus & Depithed Bagasse & 12.04 & 1.48 & $12.83^{\text {a }}$ & $44.78^{a}$ & 6.28 & {$[43]^{\S}$} \\
\hline P. ostreatus & Bagasse from mills & 11.08 & 1.94 & $12.89^{\mathrm{a}}$ & $45.14^{\mathrm{a}}$ & 5.81 & {$[43]^{\S}$} \\
\hline P. cystidiosus & Corncob & 17.20 & 3.00 & $24.25^{\mathrm{a}}$ & $40.64^{\mathrm{z}}$ & 7.57 & {$[37]^{\S}$} \\
\hline P. cystidiosus & Sugarcane bagasse & 15.54 & 2.30 & $22.79^{\text {a }}$ & $45.25^{\mathrm{z}}$ & 7.48 & {$[37]^{\S}$} \\
\hline P. cystidiosus & Sawdust:corncob (50:50) & 15.05 & 2.80 & $23.58^{a}$ & $44.85^{\mathrm{z}}$ & 7.30 & {$[37]^{\S}$} \\
\hline P. cystidiosus & Sawdust:sugarcane bagasse (50:50) & 13.08 & 3.28 & $24.50^{\mathrm{a}}$ & $46.86^{\mathrm{z}}$ & 6.70 & {$[37]^{\S}$} \\
\hline P. cystidiosus & Sawdust:sugarcane bagasse $(80: 20)$ & 12.58 & 3.33 & $25.05^{\mathrm{a}}$ & $47.27^{\mathrm{z}}$ & 6.40 & {$[37]^{\S}$} \\
\hline P. cystidiosus & Sawdust:corncob $(80: 20)$ & 11.84 & 2.33 & $22.45^{\mathrm{a}}$ & $51.93^{z}$ & 6.39 & {$[37]^{\S}$} \\
\hline P. cystidiosus & Sawdust & 10.99 & 2.05 & $20.05^{\mathrm{a}}$ & $55.92^{z}$ & 6.30 & {$[37]^{\S}$} \\
\hline
\end{tabular}

$\S$ Data were recalculated as $\mathrm{N} \times 4.38,{ }^{\mathrm{a}}$ data obtained by AOAC procedure, ${ }^{\mathrm{z}}$ total carbohydrates determined by difference.

Table 4. Biological efficiency (BE \%) of some Pleurotus spp. species cultivation on different processing-based residues.

\begin{tabular}{lccc}
\hline Species & Substrate & BE & References \\
\hline P. cystidiosus & Corncob & 50.1 & {$[37]$} \\
P. cystidiosus & Sugarcane bagasse & 49.5 & {$[37]$} \\
P. cystidiosus & Sawdust:sugarcane bagasse (50:50) & 44.1 & {$[37]$} \\
P. cystidiosus & Sawdust (acacia):corncob (50:50) & 43.6 & {$[37]$} \\
P. cystidiosus & Sawdust:sugarcane bagasse (80:20) & 41.2 & {$[37]$} \\
P. cystidiosus & Sawdust (acacia):corncob (80:20) & 38.4 & {$[37]$} \\
P. cystidiosus & Sawdust (acacia) & 36.3 & {$[37]$} \\
P. eryngii & Composted two-phase olive mill wastes: wheat straw (40:60) & 120.0 & {$[49]$} \\
P. eryngii & Composted two-phase olive mill wastes: wheat straw (20:80) & 119.8 & {$[49]$} \\
P. eryngii & Two-phase olive mill wastes: wheat straw (20:80) & 96.1 & {$[49]$} \\
P. eryngii & Grape marc:wheat straw (1:1) & 87.2 & {$[50]$} \\
P. eryngii & Composted two-phase olive mill wastes: wheat straw (60:40) & 86.8 & {$[49]$} \\
P. eryngii & Olive leaves: Two-Phase Olive Mill Waste (1:1) & 73.3 & {$[50]$} \\
P. eryngii & Cotton waste & 71.6 & {$[51]$} \\
P. eryngii & Two-phase olive mill wastes: wheat straw (40:60) & 68.9 & {$[49]$} \\
\hline
\end{tabular}


Table 4. Cont.

\begin{tabular}{|c|c|c|c|}
\hline Species & Substrate & BE & References \\
\hline P. eryngii & Corncob & 51.8 & [51] \\
\hline P. eryngii & Grape marc:wheat straw $(1: 1)$ & 48.2 & [50] \\
\hline P. eryngii & Olive leaves: Two-Phase Olive Mill Waste (1:1) & 42.3 & [50] \\
\hline P. eryngii & Sugarcane bagasse & 41.3 & [51] \\
\hline P. eryngii & Sawdust (acacia) & 35.5 & [51] \\
\hline P. eryngii & Two-phase olive mill wastes: wheat straw (60:40) & 30.9 & [49] \\
\hline P. florida & Coir pith $+4 \%$ CaSO 4 & 74.2 & [52] \\
\hline P. florida & Coir pith $+6 \% \mathrm{MgSO} 4$ & 52.2 & [52] \\
\hline P. florida & Coir pith $+0.4 \%$ FeSO 4 & 27.5 & [52] \\
\hline P. florida & Coir pith $+0.2 \% \mathrm{ZnSO} 4$ & 22.7 & [52] \\
\hline P. ostreatus & Grape marc + cotton gin trash $(1: 1)$ & 137.2 & [42] \\
\hline P. ostreatus & Composted two-phase olive mill wastes: wheat straw (20:80) & 135.3 & [49] \\
\hline P. ostreatus & Composted two-phase olive mill wastes: wheat straw (40:60) & 125.5 & [49] \\
\hline P. ostreatus & Two-phase olive mill wastes: wheat straw $(20: 80)$ & 107.6 & [49] \\
\hline P. ostreatus & Sugar cane Trash & 106.6 & [43] \\
\hline P. ostreatus & Trash/bagasse mixture & 103.5 & [43] \\
\hline P. ostreatus & Grape marc:wheat straw $(1: 1)$ & 98.0 & [50] \\
\hline P. ostreatus & Grounded corncob & 91.2 & [64] \\
\hline P. ostreatus & Composted two-phase olive mill wastes: wheat straw (60:40) & 88.3 & [49] \\
\hline P. ostreatus & Sawdust & 85.7 & [64] \\
\hline P. ostreatus & Grape marc:wheat straw (1:1) & 84.1 & [50] \\
\hline P. ostreatus & Two-phase olive mill wastes: wheat straw (40:60) & 84.1 & [49] \\
\hline P. ostreatus & Sawdust:grounded corncob (40:60) & 77.2 & [64] \\
\hline P. ostreatus & Leaves and two-phase olive mill waste (1:1) & 71.6 & [42] \\
\hline P. ostreatus & Sugarcane leaves & 71.0 & [54] \\
\hline P. ostreatus & Bagasse from mills & 70.1 & [43] \\
\hline P. ostreatus & Sawdust:grounded corncob (60:40) & 68.4 & [64] \\
\hline P. ostreatus & Hazelnut husk: wheat straw: wheat bran (1:2:1) & 67.4 & [53] \\
\hline P. ostreatus & Depithed Bagasse & 66.6 & [43] \\
\hline P. ostreatus & Hazelnut husk:wheat straw:wheat bran (1.5:2:0.5) & 66.3 & [53] \\
\hline P. ostreatus & Corncob & 66.1 & [37] \\
\hline P. ostreatus & Sugarcane bagasse & 65.7 & [37] \\
\hline P. ostreatus & Cotton waste & 59.4 & [55] \\
\hline P. ostreatus & Sawdust:sugarcane bagasse (50:50) & 58.9 & [37] \\
\hline P. ostreatus & Sawdust (acacia):corncob (50:50) & 58.8 & [37] \\
\hline P. ostreatus & Pine needles & 55.7 & [42] \\
\hline P. ostreatus & Olive leaves: Two-Phase Olive Mill Waste (1:1) & 55.4 & [50] \\
\hline P. ostreatus & Sawdust:sugarcane bagasse (80:20) & 52.3 & [37] \\
\hline P. ostreatus & Sugarcane bagasse & 50.4 & [54] \\
\hline P. ostreatus & Sawdust (acacia): corncob (80:20) & 49.0 & [37] \\
\hline P. ostreatus & Sawdust (acacia) & 46.4 & [37] \\
\hline P. ostreatus & Two-phase olive mill wastes: wheat straw (60:40) & 45.4 & [49] \\
\hline P. ostreatus & Grape marc:wheat straw (1:1) & 45.1 & [50] \\
\hline P. ostreatus & Beech sawdust & 33.5 & [42] \\
\hline P. ostreatus (local) & Solid olive mill wastes:CaCO3:wheat straw $(88: 2: 10)$ & 33.1 & [65] \\
\hline P. ostreatus & Corncob & 31.7 & [42] \\
\hline P. ostreatus (commercial) & Solid olive mill wastes:CaCO3:wheat straw (88:2:10) & 29.8 & [65] \\
\hline P. ostreatus & Corncobs & 28.3 & [55] \\
\hline P. ostreatus & Olive leaves: Two-Phase Olive Mill Waste (1:1) & 26.9 & {$[50]$} \\
\hline P. ostreatus & Date palm tree leaves & 24.7 & [42] \\
\hline P. ostreatus & Extracted olive-press cake & 18.8 & [42] \\
\hline P. ostreatus & Olive leaves: Two-Phase Olive Mill Waste (1:1) & 17.9 & [50] \\
\hline P. ostreatus (local) & Solid olive mill wastes & 10.3 & [65] \\
\hline P. ostreatus (commercial) & Solid olive mill wastes & 11.5 & {$[65]$} \\
\hline P. ostreatus & Jatropha cake & 0 & [55] \\
\hline P. pulmonarius & Composted two-phase olive mill wastes: wheat straw (20:80) & 125.8 & [49] \\
\hline P. pulmonarius & Composted two-phase olive mill wastes: wheat straw (40:60) & 116.5 & [49] \\
\hline P. pulmonarius & Two-phase olive mill wastes: wheat straw $(20: 80)$ & 116.3 & [49] \\
\hline P. pulmonarius & Two-phase olive mill wastes: wheat straw (40:60) & 86.4 & [49] \\
\hline P. pulmonarius & Composted two-phase olive mill wastes: wheat straw (60:40) & 81.3 & [49] \\
\hline P. pulmonarius & Two-phase olive mill wastes: wheat straw $(60: 40)$ & 42.0 & [49] \\
\hline P. sajor-caju & Hazelnut husk: wheat straw: wheat bran (1.5:2:0.5) & 71.0 & [53] \\
\hline P. sajor-caju & Hazelnut husk: wheat straw: wheat bran (1:2:1) & 66.3 & [53] \\
\hline P. sapidus & Hazelnut husk: wheat straw: wheat bran (1.5:2:0.5) & 44.2 & [53] \\
\hline P. sapidus & Hazelnut husk: wheat straw: wheat bran (1:2:1) & 41.1 & [53] \\
\hline
\end{tabular}

\subsection{Olive Mill Wastes}

The olive-oil industry is a very important economic sector for the countries of the Mediterranean area. However, it is well known that the oil production process produces large volumes of wastes. 
According to the centrifugation system used by the industry to extract oil, different fractions can be obtained at the end of the process [66]. In the three-phase system the oily phase, the olive pomace (or olive husk or olive press cake) and the olive mill wastewater are produced, while the extraction with the more recent two-phase system leads to the oily phase and to a viscous sludge-like waste (called in different ways: alperujo, olive wet husk, wet pomace, or two-phase olive mill waste). Although the two-phase system has been labeled as ecological because of the reduction in water consumption, the effective management and safe disposal of all the wastes generated by both systems, previously described, are a serious problem of environmental pollution, also because they are produced in a short period of time. According to Ntougias, et al. [67], in fact, these residues are characterized by acidic $\mathrm{pH}$, high phenolic and organic matter contents, undesirable color and odor. Their use in livestock feeding is limited due to the presence of anti-nutritional compounds, such as phenols, and the high lignin content, which prevents the action of both rumen microorganisms and hydrolytic enzymes [68]. Many studies reported, in the literature, the evaluation of the lignin-degrading enzymatic system of selected white-rot fungi as a useful tool to decrease the phenolic content and the phytotoxicity of the olive mill wastes $[69,70]$, but few of them evaluate the effects of the olive mill wastes supplementation on the growth, chemical composition or nutritional quality of mushrooms.

Avni, et al. [71] investigated the use of olive mill solid waste (OMSW) from three-phase olive mills in the substrate cultivation of different Pleurotus species, particularly focusing on the glucan contents of mushrooms. The authors were able to enhance up to twice the total glucan content when using OMSW in combination with eucalyptus sawdust (80:20) in the growth substrate compared to no OMSW use. This result was in agreement with those of Reverberi, et al. [72], according to which substrate containing OMSW stimulated the $\beta-1,3$-glucan synthesis in P. ostreatus, due to the mushroom response to the oxidative stress that may occur in the presence of OMSW. Furthermore, Avni, et al. [71] observed a great difference in the glucan contents among the various Pleurotus species, with the maximal variation in the $\alpha$-glucan concentrations and P. eryngii being the species with the highest $\alpha$-and $\beta$-glucan contents, $\alpha$-glucan being mainly concentrated in the stalk.

Similarly, Mansour-Benamar, et al. [65] tried to valorize olive mill wastes, by evaluating the use of solid olive mill wastes alone (SOMW) and supplemented with wheat straw (SOMWS) for the growth of two strains of oyster mushroom, a local and a commercial strain of Pleurotus ostreatus. Mushroom growth was observed in both substrates, but the yields were very low. The lower mushroom productivities were probably due to the poor nitrogen supply present in the SOMW: solid olive mill wastes supplementation with wheat straw, in fact, significantly increased the productivity of both Pleurotus strains (Table 4).

Ruiz-Rodriguez, et al. [73], instead, evaluated the effects of wheat straw supplemented with olive mill waste, obtained from a two-phase olive oil production system, on the growth and quality of P. ostreatus and P. pulmonarius: high biological efficiency (up to $85 \%$ ) where observed on substrates including up to $50 \%$ of olive mill waste, while higher supplementations lead to a significant reduction in the BE values.

Similarly, Zervakis, et al. [49] evaluated the use of two-phase olive mill wastes (TPOMWs) in the growth substrates of different Pleurotus species. When composted media were used the authors obtained a better yield, especially at low TPOMWs concentrations (20-40\% for composted media and $20 \%$ for raw TPOMWs): the composting process, in fact, leads to a detoxification of the original material. The mushrooms productivity decreased when raw TPOMWs supplementation exceeded $60 \%$, probably due to the high toxicity of the waste present in the growth substrate. The results of this study showed very high BE values, the highest BE being obtained from the composted TPOMW $20 \%$ and ranging between $120 \%$ and $135 \%$ (Table 4 ). As concerning the different species, P. cystidiosus showed the poorest performances, while P. ostreatus and P. pulmonarius were the fastest colonizers. 


\subsection{Grape Marc}

Grape wine is one of the most important alcoholic beverages in the world, with a continuously increasing demand. It has been calculated that the wine industry produces wastes at about 5 tons per hectare of land per year [74], generating both solid and liquid wastes. Solid winery waste is composed of grape stalks, grape seeds, and grape marc. Grape stalks are rich in lignin, cellulose, nitrogen, and potassium and have been found to be highly effective for soils [75]. Grape seeds are very rich in linoleic acid and omega- 6 fatty acids, and phenolic compounds [76], and therefore can be used for the extraction of these bioactive molecules. Grape pomace is generally used as feed additive due to its high fiber content (up to $40 \%$ ), but it also contains sugars, pigments and phenolic compounds [74]. Thanks to their high lignocellulose contents, solid winery wastes could be good candidates as growth substrates for mushrooms cultivation.

Koutrotsios, et al. [42] evaluated different plant residues as substrates for the cultivation of $P$. ostreatus, observing that grape marc plus cotton gin trash $(1: 1, w / w)$ gave the best biological efficiency, followed by olive mill by-products (leaves and two-phase olive mill waste 1:1, w/w), 137 and 72\%, respectively (Table 4). Moreover, the authors observed a strong positive correlation between BE and the crude protein content of the best performing substrates $\left(\mathrm{r}^{2}=0.912\right)$. A strong correlation was also observed between $\mathrm{BE}$ and the lignin content of the best performing substrates $\left(\mathrm{r}^{2}=0.906\right)$, whereas crude fiber, hemicellulose, and total carbohydrates contents showed negative correlation with BE.

Koutrotsios, et al. [50], instead, showed an increase in triterpenic compounds (oleanolic and ursolic acids and erythrodiol), as well as in resveratrol and ergosterol contents, in different species of Pleurotus spp. with increasing grape marc ratio to wheat straw used as a basal growth substrate. At the same time, the increased percentage of grape marc to wheat straw resulted in an increase in the total phenolic content and antioxidant activity (DPPH and FRAP) of the studied mushrooms.

Petre, et al. [77] evaluated the effects of the addition of different sources of nitrogen $(1 \% w / v$ of rice bran, malt extract, peptone, trypeptone or yeast extract) and minerals (5 mg of $\mathrm{CaCO}_{3}, \mathrm{KH}_{2} \mathrm{PO}_{4}$, $\mathrm{K}_{2} \mathrm{HPO}_{4}$, or $\mathrm{MgSO}_{4} \cdot 5 \mathrm{H}_{2} \mathrm{O}$ ) to the growth substrate composed of grape marc for P. ostreatus cultivation. Rice bran was the best performing $\mathrm{N}$ source, closely followed by the malt extract, whereas $\mathrm{CaCO}_{3}$ revealed the most appropriate mineral source.

\subsection{Brewers Grain}

The most abundant brewing by-product is brewers' spent grain (BSG): it has high water and fermentable sugar contents, which make it very unstable and easily perishable due to microbial activity [78]. BSG is generally used for animal feed, but other applications involve BSG in human nutrition, energy and charcoal production, in the paper manufacturing, as a brick component and as adsorbent [78]. BSG is a lignocellulosic material, it is rich in protein and fiber, therefore, it is reasonable to consider it a suitable substrate for the mushroom growth. Very few works are present in the literature regarding brewers' spent grains for the cultivation of edible mushrooms. Wang, et al. [79] used unpretreated spent beer grains (added with different nitrogen sources: wheat, rice, and corn brans and Okara) as a substrate for the cultivation of Pleurotus ostreatus, yielding mushrooms with higher nutritional value than those grown on other reported kinds of substrates. The authors observed the major effect of the different substrates on the protein content, but also on carbohydrates and ash values of the fruit bodies, while the fat contents were quite similar. Furthermore, the amount and particularly the nature of the nitrogen source of the substrate influenced in a different way the protein content of the fruit bodies: few fruit bodies were observed when using spent grain alone as substrate, while the highest mushroom yield was obtained on a substrate composed of $45 \%$ wheat bran and $55 \%$ BSG. Gregori, et al. [80], instead, yielded the maximum biological efficiency of the fruit bodies of $P$. ostreatus grown on a substrate composed of $20 \%$ wheat bran, $10 \%$ BSG, $68 \%$ beech sawdust and $2 \%$ $\mathrm{CaCO}_{3}$. The authors [80] attributed the observed differences with the results of Wang, et al. [79] to the various beer manufacturing processes or to the different fungal strains used. 


\subsection{Coconut Husk/Coir}

Coconut palms generally grow in the tropical regions, but the big majority of the commercially produced coir comes from India and Sri Lanka, Indonesia and Philippines being the other major countries. Once harvested, the whole coconut is separated into kernel and husk, where the kernel is used either directly as food or processed further into food products or oil. The husk undergoes the extraction of coir fiber, from whose process coir pith is obtained as a by-product (about $50-70 \%$ of the husk). Despite many advantages and availability in large quantities, coir pith is not fully utilized for productive purposes and every year large amounts of coir pith accumulate nearby coir processing units, causing severe disposal problems, fire hazards and groundwater contamination due to the release of phenolic compounds [81]. Coir pith has high $\mathrm{C} / \mathrm{N}$ ratio (about 100:1) and high lignin content, making its degradation under natural conditions very slow and preventing its direct use as an organic fertilizer [81]. Just for its high lignin content, many species of Pleurotus have been employed for coir pith degradation.

Raja, et al. [52] evaluated the effects of different mineral sources (sulfate forms of calcium, magnesium, iron, and zinc) addition to coir pith and paddy straw as basal substrates in the cultivation of $P$. florida. The obtained results showed that coir pith always had worse yield and biological efficiency compared to paddy straw, and among the different mineral sources, calcium sulfate addition gave the highest yield and BE values: $360.0 \mathrm{~g} \mathrm{bag}^{-1}$ and $74.2 \%$ for coir pith and $463.3 \mathrm{~g} \mathrm{bag}^{-1}$ and $95.5 \%$ for paddy straw, respectively.

\subsection{Coffee Pulp/Husk}

Coffee is one of the most consumed beverages in the world, due to its great demand, the coffee industry produces large amounts of residues. Depending on the coffee cherries processing method, i.e., wet or dry process, coffee pulp or coffee husk can be obtained as by-products, while the processing of raw coffee powder to prepare instant coffee generates coffee spent grain as by-products [82]. All these solid coffee wastes contain compounds, such as caffeine, tannins, and polyphenols, which make them toxic and prevent their beneficial use, besides being cause of environmental pollution problems [82]. Alternative uses of the coffee pulp and husk include their use as fertilizers, livestock feed, compost, etc., but all these applications make partial use of the coffee industry residues. However, coffee wastes are rich in organic nutrients, therefore, solid-state fermentation by mushrooms could be employed for their bioconversion processes. Parani and Eyini [83], for example, investigated the biodegradation potential of selected fungal monocultures (among which P. eous and P. flabellatus) and their co-cultures in degrading coffee pulp: the authors observed protein enrichment (linear increase with the vegetative growth) and a significant loss in the organic matter of the coffee pulp during solid state biodegradation. Similarly, García, et al. [84] studied the production of ligninolityc enzymes of $P$. ostreatus and P. pulmonarius cultivated on coffee pulp: an increase in laccase activity was observed in mushrooms grown on coffee pulp with the simultaneous decrease of the caffeine and phenolic contents in the substrate. Furthermore, mixtures (1:1) of coffee pulp with cedar chip, coconut and cocoa shells showed that pure coffee pulp had higher laccase activity compared to mixtures with other by-products.

Da Luz, et al. [85] evaluated the P. ostreatus growth on different agro-industrial wastes, among which coffee husks with or without $20 \%$ rice bran. Also, in this case, coffee husks alone gave worse results: higher values of $\mathrm{BE}$, enzyme (MnP, laccase, cellulase, and xylanase) activities, and soluble protein content were, in fact, observed in substrates added with $20 \%$ rice bran. The authors attributed the increasing enzyme activities to the major availability of monosaccharides, polysaccharides or nitrogen due to the addition of rice bran, and they highlighted the importance of reducing the $\mathrm{C} / \mathrm{N}$ ratio of the growth substrates by adding a nitrogen source, in order to improve the mushroom cultivation. 


\subsection{Corncob}

Corncob is one of the major agricultural by-products (tens of million tons) in the European Union [42]. To prevent farmers from disposing of the corncob excess by burning them, this by-product could be a cheap substrate for oyster mushrooms cultivation.

Buah, et al. [64] evaluated the possibility of using grounded corncob as an alternative to sawdust for mushrooms growth since it is very firm and retains a good amount of water. In this study the substrate composed of corncob and wheat bran showed better results than that composed of sawdust and wheat bran in terms of the growth and yield of P. ostreatus mushrooms (Table 4): when mixing with sawdust $(40 \%$ or $60 \%)$, in fact, corncob gave lower results in terms of the growth and yield, probably due to the $\mathrm{pHs}$ of the substrates which were lower than the optimum $\mathrm{pH}$ ranges for mushrooms growth. Also Hoa, et al. [37], in the evaluation of the effects of different substrates on the growth, yield, and chemical composition of P. ostreatus and P. cystidiosus observed that corncob (100\%), together with sugarcane bagasse (100\%) were the most suitable substrates for mushrooms growth (Table 4). In particular, the authors found that the $\mathrm{C} / \mathrm{N}$ ratios of the substrates were negatively correlated with the total colonization period, mushroom weight, yield, BE and protein content of both P. ostreatus and P. cystidiosus mushrooms. Later, Hoa, et al. [86] showed that corncob $(100 \%)$ as growth substrate for P. ostreatus and P. cystidiosus also gave the highest total phenolic and total flavonoid contents in the studied mushrooms, with consequent high antioxidant activity.

In the study of Wang, et al. [87] different agro-industrial wastes, among which corncob, were added into a basal culture medium (50.0\% eucalyptus sawdust $+10.0 \%$ wheat bran $+3.0 \%$ lime $+1.0 \%$ gypsum $+1.0 \%$ calcium superphosphate) in order to evaluate their effect on the growth parameters of P. pulmonarius. The authors observed that the growth substrate supplemented with corncob (35\%) showed the worst comprehensive performance, with biological efficiency of $62.1 \%$, the substrates supplemented with $35 \%$ of cottonseed hull, mulberry sawdust, and bagasse instead gave BE of $74.2 \%$, 72.6 and 65.4 , respectively.

The corncob particle size could influence the mushrooms growth parameters: Li, et al. [88], in fact, observed that the mycelium growth rate and the yield per bottle significantly increased in P. eryngii cultivation with the corncob particle size increasing and that the excessively small corncob particles could result in lengthening the mushrooms growth cycle.

\subsection{Sugarcane Bagasse}

Sugarcane is an ethanol and sugar source, and Brazil is the major sugarcane producer in the world. The sugarcane residue, the bagasse (SCB), is one of the most abundant agro-industry by-products in the world, producing about 540 million tons of residues per year [89]. It is generally composed of approximately $40 \%$ cellulose, $24 \%$ hemicelluloses, and $25 \%$ lignin [90], and small amounts of ash and waxes. SCB is used for electric energy production [91]. Thanks to its availability in large quantities at low cost, SCB is an attractive feedstock for the large-scale biological production of fuel ethanol [92], but it needs a preliminary lignin removal before the bioethanol production. The degradation of lignin through biological methods are superior if compared to physical and chemical pre-treatments, thanks to their mild condition, less consumption of energy and being environmentally friendly [93]. However, biological degradation of the lignin is a generally slow and difficult to control process, therefore, its applications at the industrial level are very limited. White-rot fungi could be considered a very efficient tool for the biological degradation of lignin through the microorganisms' action. For this purpose, Dong, et al. [94] studied the lignocellulosic degradation process of sugarcane bagasse by means of different white-rot fungi (P. chrysosporium, Lentinula edodes, and P. ostreatus), showing different degradation mechanisms. P. chrysosporium was the most efficient in SCB degradation, removing $73.5 \%$, $67.0 \%, 88.6 \%$ and $93.4 \%$ of total SCB, cellulose, hemicelluloses, and lignin, respectively. L. edodes and $P$. ostreatus, instead, decomposed $45.5 \%$ and $32.2 \%$ of total SCB, $15.2 \%$ and $16.3 \%$ of cellulose, $73.5 \%$ and $64.4 \%$ of hemicelluloses, and $87.6 \%$ and $84.9 \%$ of lignin, respectively. 
The evaluation of SCB as a growth substrate for P. ostreatus cultivation was also studied by Aguilar-Rivera and De Jesús-Merales [43]. Compared to the control (wheat straw), depithed bagasse and bagasse from mills increased the carbohydrate contents (Tables 1 and 3 ) of the cultivated mushrooms ( $44.78 \%$ and $45.14 \%$, compared to $40.96 \%$ of the control). The highest biological efficiency was observed in the sugarcane trash substrate (106.6\%), followed by the mixture of sugar mills bagasse with sugarcane trash $(103.5 \%)$, even if they were lower compared to BE obtained on the control substrate $(114.9 \%)$, as reported in Tables 2 and 4.

\subsection{Rice Husk}

Rice husk is a waste by-product of rice milling, it is produced in large volumes and is generally disposed of in wasteland or burned in the open, thus being cause for environmental pollution [95]. Furthermore, its high fiber content is a limiting factor for its use as component of monogastric feed [96]. For that purpose, the authors studied P. ostreatus as a tool able to ferment native rice husk (NRH) at different periods: an increment in the crude protein content of the fermented NRH was observed, with the highest value being obtained in the NRH fermented for 7 days $(+44.17 \%)$. Furthermore, the authors reported a decrease in the acid detergent fiber and neutral detergent fiber contents, together with an increase in the total amino acid content, and in particular an increase in the percentage of essential amino acids. In this way, Dairo, et al. [96] showed how the nutritive value of native rice husk can be improved by mushroom solid-state fermentation, hence making it more suitable for livestock feed utilization.

Besides being improved in its nutritional value by mushrooms solid-state fermentation, rice husk can be also used as a growth substrate for mushrooms cultivation.

Anyakorah and Dike [95] compared sawdust to rice husk as casing materials of cassava peel in order to encourage the fructification of P. pulmonarius. The authors observed a reduction in fruiting time either for sawdust $(21.4 \%)$ and rice husk $(23.8 \%)$ cased substrates, but biological efficiency increased only in sawdust casing (from $8.5 \%$ to $26.7 \%$ ), while for rice husk casing a reduction of $6.5 \%$ in $\mathrm{BE}$ was observed.

\subsection{Hazelnut Husk}

Hazelnut processing produces large quantities of shells and leaves as by-products. Hazelnut husks are raw materials particularly rich in cellulose and hemicellulose, which could be potentially used for the production of food enzymes, biofuel, and various chemicals (acetic acid, furfural, and lignin degradation products) after bioprocessing [97]. Furthermore, Çöpür, et al. [98] evaluated the chemical properties of hazelnut husks and showed that they could be used as a valuable material for the production of particleboards, while recent works focused the attention on the extraction and the effects of antioxidant compounds from hazelnut shells [99,100], highlighting their potential use as important functional ingredient in food technology or in pharmaceutical industry.

Moreover, thanks to their chemical composition, hazelnut shells could be a good candidate as a substrate in the cultivation of the mushroom. Different combinations of hazelnut wastes with other materials, such as paper wastes, were investigated for the cultivation of P. ostreatus [101].

Yildiz, et al. [102], in the evaluation of different lignocellulosic wastes as raw materials for $P$. ostreatus cultivation, reported that a mixture of sawdust with hazelnut leaves (50:50) was one of the substrates with the major biological efficiency. However, when the percentage of hazelnut leaves increased over $50 \%$, the mushrooms yields decreased, so the authors concluded that leaf of hazelnut is not very appropriate, as the growth substrate in percentages higher than $50 \%$ [102]. Pekşen and Küçükomuzlu [53], instead, evaluated the effects of different substrates containing hazelnut husks in the cultivation of different Pleurotus species (P. ostreatus, P. sajor-caju, and P. sapidus). The authors observed that the different species were statistically different in terms of total yield, BE and morphological parameters, concluding that the optimum substrate for Pleurotus growth was a combination of hazelnut husk, wheat straw and wheat bran in the ratio 1.5:2:0.5 (Table 4) However, the biological efficiencies 
of the substrates containing hazelnut husks were lower compared to BE of the control composed of wheat straw $+5 \%$ wheat bran (Tables 2 and 4 ).

\section{Aspects Related to Pleurotus spp. Cultivation on Agri-Food by-Products}

The influence of many agri-food residues, used as growth substrates for mushrooms cultivation, on the chemical composition and production parameters of different species of Pleurotus are reported in Tables 1 and 2 for field-based residues, and in Tables 3 and 4 as concerning processing-based residues.

Within the same species, protein content seems to be the mushroom nutrient most influenced by the type of growth substrate, followed by crude fiber and carbohydrates. The genus Pleurotus is generally characterized by high protein content [103] on a dry weight basis and can be considered a good source of protein, especially for vegetarians [104]. However, when comparing mushrooms proteins, particular attention must be paid to the conversion factor used to express $\mathrm{N}$ content. Many studies regarding edible mushrooms, in fact, overestimated protein content (calculated as $\mathrm{N} \times 6.25$ ) due to the high proportion of non-protein nitrogen, particularly in chitin [24]. Therefore, a conversion factor equal to 4.38 is more appropriate [105]. Keeping this in mind, Tables 1 and 3 were filled out using 4.38 as a conversion factor in order to compare Pleurotus spp. protein content.

Within the same species, the differences in proximate composition are indeed due to the characteristics of the growth substrate, as well as to the strain employed. However, this information is most often lacking in the scientific literature [41,45] making the comparison among results rather difficult.

P. sajor-caju showed the highest protein content among the different Pleurotus species (Table 1). In any case, the genus Pleurotus showed protein contents similar to or higher than those found in many vegetables, but lower than meat and cheese contents [106].

High protein contents are obtained from cultivation on substrates rich in nitrogen [43] or supplemented with other nitrogen sources [37,44]. This would justify the higher value of protein content reported in Table 1 by Koutrotsios, et al. [42] when P. ostreatus is cultivated on pine needles compared to wheat straw ( 22.74 vs. 14.64 , respectively). The same authors also reported a negative correlation between mushroom crude protein and substrates hemicellulose.

Low $\mathrm{C} / \mathrm{N}$ ratio of the growth substrate yielded high protein content in mushrooms [37]. For this reason, P. ostreatus and P. cystidiosus cultivated on corncob $(\mathrm{C} / \mathrm{N}=34.57)$ showed the highest protein content, while the same mushrooms cultivated on sawdust $(\mathrm{C} / \mathrm{N}=51.71)$ had the lowest value, as reported in Table 2 [37]. At the same time, wheat straw $(\mathrm{C} / \mathrm{N}$ ratio $=34.22)$ used by Gupta, et al. [44] showed the lower protein content (Table 1) compared to other growth substrates composed of wheat straw supplemented with mahua-cake by-products $(\mathrm{C} / \mathrm{N}$ ratios $<15)$.

Regarding the fat contents in mushrooms, Tables 1 and 3 confirmed that Pleurotus spp. are foods with very low-fat content [22,24], with values being lower than $4 \%$. Koutrotsios, et al. [42] reported a positive correlation between mushroom fat content and $\mathrm{C} / \mathrm{N}$ ratio and cellulose content of the growth substrates, while a negative correlation was observed between mushroom fat content and substrates fat content. For this reason, P. ostreatus cultivated on beach sawdust, corncob, and date palm tree leaves showed the highest fat content in Table 3 [42], while the same mushroom cultivated on extracted olive-press cake showed the lowest fat value. The correlation observed by the same authors could also justify the results reported by Gupta, et al. [44], as well as data showed in Table 1, in which P. sajor-caju cultivated on wheat straw had the highest fat content $(2.07 \%)$ compared to other substrates (fat < $1.85 \%$ ): the authors, in fact, reported a $\mathrm{C} / \mathrm{N}$ ratio and cellulose content equal to $34.22 \%$ and $34.23 \%$, respectively, for wheat straw, while the other growth substrates showed values significantly lower $(\mathrm{C} / \mathrm{N}$ ratio $<15$ and cellulose content $<20 \%$ ). Furthermore, these substrates also showed higher fat contents $(>5 \%)$ compared to wheat straw $(0 \%)$. Nevertheless, fat values of oyster mushrooms grown on different substrates reported by Hoa, et al. [37] and shown in Table 3 do not exhibit the same trend of $\mathrm{C} / \mathrm{N}$ ratio of the substrates: probably there were other factors influencing fat content in mushrooms, but the authors did not report other useful information about the growth substrates composition. 
Regarding the fiber and carbohydrates contents of mushrooms, values can be deeply affected by the analytical method used for their determination, which makes rather difficult the comparison of the results. Tables 1 and 3 , in fact, show a wide range for these nutrients in the Pleurotus genus. $P$. ostreatus had the highest crude fiber content, ranging from $12.39 \%$ [43] to $29.75 \%$ [37], followed by P. sapidus (crude fiber between $6.00 \%$ and $8.00 \%$ ), and P. eous (crude fiber in the range $7.30-9.00 \%$ ). Fiber contents in the mushroom are generally determined by the AOAC enzymatic gravimetric method [104]. However, the presence in the residue of non-protein nitrogen originating from chitin (of which mushrooms are rich) could deeply affect the results [104]. Koutrotsios, et al. [42] observed that carbohydrates content in P. ostreatus was positively correlated with substrates $\mathrm{C} / \mathrm{N}$ ratio, cellulose and hemicellulose content, and negatively correlated with substrates fat content. For this reason, their results reported in Table 3 show that P. ostreatus cultivated on beech sawdust and corncob (substrates with very high $\mathrm{C} / \mathrm{N}$ ratio, 427.2 and 112.4 , respectively, and very low fat contents, $0 \%$ and $0.6 \%$, respectively) had the highest carbohydrates values, while the same mushroom cultivated on almond and walnut shell $(\mathrm{C} / \mathrm{N}$ ratio $=39.2$ and fat content $=6.1 \%)$ showed the lowest carbohydrates value (56.64\%). A similar trend between mushrooms carbohydrate content and substrates $\mathrm{C} / \mathrm{N}$ ratio can be observed in the results of Hoa, et al. [37] reported in Table 3 for both P. ostreatus and P. cystidiosus.

Results reported by Gupta, et al. [44] in Table 1 show that increase in sugar of the growth substrates (through supplementation of wheat straw with mahua-cake by-products) does not correspond to increase in mushroom sugars: the authors attributed this to the absorption of these nutrients by mushrooms to increase the growth of the fruit bodies rather than specifically increasing their sugar content.

Some authors also attributed carbohydrates trend in mushrooms to differences in protein contents: Shashirekha, et al. [107], for example, observed carbohydrates decrease in mushroom cultivated on rice straw supplemented with cottonseed compared to rice straw alone, but the authors attributed this reduction to the significant increase in mushroom protein content.

Results reported in Tables 1 and 3 show that Pleurotus spp. minerals content ranges between 6 and $10 \%(\mathrm{dw})$. Differences in the mushroom ash contents depend on the substrate salts content [108]. Variations in mineral compositions may be due to the adsorption and accumulation of these elements by mushroom from the growth substrate [51], and to the availability of these nutrients in the substrates. Furthermore, minerals contents in mushrooms fruiting bodies are generally species-dependent [109]. This was also confirmed by Hoa, et al. [37] results reported in Table 3 concerning ash content in $P$. ostreatus and P. cystidiosus cultivated on the same lignocellulosic materials.

Nitrogen supplementation is an important factor affecting mushroom growth: Mane, et al. [56] observed significant increase in yields of Pleurotus sajor-caju when lignocellulosic agricultural substrates were supplemented with $1 \%$ organic nitrogenous material by addition of gram flour or groundnut oil seed cake or rice bran.

Tables 2 and 4 show the biological efficiencies of Pleurotus spp. cultivated on different agri-food wastes. The form of nitrogen seems to play an important role in mushrooms growth: according to Mikiashvili, et al. [110], in fact, the addition of nitrogen-rich organic supplements enhances the activities of laccase and $\mathrm{Mn}$-dependent peroxidase in mushrooms, hence promoting their growth. Also Nunes, et al. [111] evaluated the addition of different nitrogen forms (rice bran and urea) to substrates for P. ostreatus cultivation: nitrogen supplementation, especially in the organic form (rice bran) enhanced mushrooms biological efficiency. The authors also observed that urea supplementation inhibited the assimilation of phosphorus, potassium, and magnesium by mushrooms in some substrates, because it may act as chelator, thus decreasing the availability of substrate minerals [111].

Formerly, also Koutrotsios, et al. [42] observed that high nitrogen contents (preferably in the organic form) in the growth substrates improved mushrooms biological efficiency, even if in some cases nitrogen contents over a specific threshold $(\mathrm{N}>1.4 \%)$ were associated with a decrease in yields [112]. The assessment of the prohibitive $\mathrm{N}$ levels, however, is very difficult since mushrooms yields depend on many other factors, such as availability (not just presence) of nutrients, presence of toxic compounds, 
the formation of potentially inhibitory compounds, etc. [42]. More than nitrogen alone, in some cases $\mathrm{C} / \mathrm{N}$ ratio seems to be more significant in determining mushrooms productivity. Hoa, et al. [37], in fact, observed better mushroom yields in substrates with lower $\mathrm{C} / \mathrm{N}$ ratio, increasing for example the percentage of corncob (low $\mathrm{C} / \mathrm{N}$ ratio) or sugarcane bagasse (low $\mathrm{C} / \mathrm{N}$ ratio) in mixture with sawdust (high $\mathrm{C} / \mathrm{N}$ ratio). The same results were observed by the authors both for P. ostreatus and P. cystidiosus cultivation [37] in Table 4. The $\mathrm{C} / \mathrm{N}$ ratio of the substrate for mushroom cultivation can be up to $40-50$ since they are able to extract nitrogen nutrient even when it is present in low amount [65].

Also, mineral and lignin contents of the substrate showed a positive correlation with mushrooms biological efficiency in P. ostreatus and P. cystidiosus cultivation [42]. Different amendments of micronutrients to the growth substrates of $P$. florida also lead to different mushroom productivity in terms of BE [52], as reported in Tables 2 and 4.

Biological efficiency also showed positive and negative correlations with contents of lignin and hemicellulose, respectively, of the substrates [42,113]: low hemicellulose content combined with high lignin content, in fact, seem to effectively induce the activities of the related degrading enzymes, especially when other nutrients (such as carbohydrates and, to a small extent, fats) are not abundant [42]. A positive correlation between cellulose content of the growth substrate and biological efficiency was also observed [55,113]. High contents of cellulose are generally found in cotton wastes [11]. This could explain the generally high values of biological efficiency (Table 4) observed when Pleurotus spp. are cultivated on substrates that contain, even in part, these residues $[42,51,56,59,60]$.

Straw-based substrates or sawdust, fermented or not, with added supplements, are the general substrates for commercial Pleurotus cultivation [11]. Results reported in Tables 2 and 4 confirm that cereal straws and sawdust are the most used substrates for Pleurotus spp. cultivation, wheat straw being the major one. Wheat straw and sawdust generally provide cellulose, hemicellulose, and lignin, which are utilized during spawn growth and fructification [102,114,115]. Biological efficiency of these substrates considerably differs, with sawdust generally showing lower value than wheat straw (see Tables 2 and 4), as already observed [42]: this can be attributed to the lower delignification rate of sawdust [55], that is to say to the higher $\mathrm{C} / \mathrm{N}$ ratio of sawdust compared to wheat straw [11], since mushroom ligninolytic activity is induced in nitrogen-rich medium [116].

Regarding field-based residues for Pleurotus spp. cultivation (Table 2), cereals straw alone generally achieves biological efficiency values higher than $50 \%$. In order to consider the Pleurotus cultivation profitable the value of BE must be over 50\% [117], while, regarding yield, under ideal growth conditions $1 \mathrm{~kg}$ of the well colonized substrate should yield about $1 \mathrm{~kg}$ of marketable mushrooms [11]. Unfortunately, data regarding yields are not always comparable in the literature, due to the differences in the measurement units to express it and/or to the lack of information (e.g., weight of the growth substrates).

Data reported in the work of Sardar, et al. [51] is an exception to BE values higher than $50 \%$ in Pleurotus spp. cultivation (Table 2). However, if comparing these results with those reported by Zervakis, et al. [49] on the same Pleurotus species (P. eryngii), differences in BE may be probably due to differences in the composition of the substrate: wheat straw employed by Sardar, et al. [51], in fact, had higher hemicellulose (27.2\% vs. $21.8 \%)$ and lower lignin $(11.4 \%$ vs. $19.1 \%)$ contents than wheat straw used in the study of Zervakis, et al. [49]. Both these substrates components have been proven to have negative and positive correlation, respectively, with biological efficiency [42,113]. The same conclusion may be drawn comparing the biological efficiencies of P. ostreatus grown on wheat straw in the works of Zervakis, et al. [49] and Koutrotsios, et al. [42]: in the former study, the growth substrate had lower $\mathrm{C} / \mathrm{N}$ ratio, lower hemicellulose, and higher lignin contents, thus yielding higher biological efficiency. Unfortunately, data concerning chemical composition of the substrates are often lacking in many scientific works $[41,45,48,53-56]$, thus preventing the comparison among results.

Furthermore, with the same growth substrate, different species of the genus Pleurotus showed different behavior: P. sapidus gave the lowest biological efficiency, compared to $P$. sajor-caju and $P$. 
ostreatus when cultivated on wheat straw $+5 \%$ wheat bran [53], while P. pulmonarius gave the highest value of $\mathrm{BE}$, followed by P. eryngii and P. ostreatus when cultivated on wheat straw [49].

The low yields of mushrooms grown on some agricultural by-products, such as groundnut haulms [56], probably due to their high moisture-holding capacity, may be increased by simple addition of other agricultural by-products with lower water holding capacity, such as wheat straw, thus increasing BE values from $36.5 \%$ to $63.6 \%$ [56], as reported in Table 2.

Cereal straws or cereal milling by-products (such as wheat bran) may also be used as supplements to food industry residues in mushroom growth substrates thanks to their composition [11,114,115]. Furthermore, straw could improve the structure of the substrate [65], providing channels to oxygen inflow through the growth medium. For these reasons, the results reported in Table 4 show that processing-based residues added with wheat straw or wheat brain gave better yields for mushroom cultivation $[49,53,65]$. In particular, Pekşen and Küçükomuzlu [53] showed (Table 4) that wheat bran and wheat straw in combination with hazelnut husks allowed the fructification of different species of Pleurotus, and once again P. sajor-caju and P. ostreatus gave higher biological efficiencies $(>60 \%)$ compared to P. sapidus $(<50 \%)$. However, even if hazelnut husk is a good candidate for mushroom growth thanks to its excellent contents of lignocellulosic material and nitrogen, as well as a $\mathrm{C} / \mathrm{N}$ ratio of about 50-60 [11], wheat straw supplemented with only $5 \%$ of wheat bran gave higher biological efficiency value $(92.5 \%$, as reported in Table 2$)$ : this was probably due to the higher cellulose/lignin ratio of wheat straw (2.2-5.3, as reported by Philippoussis [11]) and wheat bran (6.19, calculated according to data reported by Claye, et al. [114]) compared to cellulose/lignin ratio of hazelnut husks $(0.7-1.2$, as reported by Philippoussis [11]), this ratio having been positively correlated with yields in $P$. ostreatus and P. pulmonarius cultivation [11].

The high value of cellulose/lignin ratio observed in cotton wastes (5.0-11.2, as reported by Philippoussis [11]) could also justify the higher biological efficiencies observed (Table 4) when P. eryngii and P. ostreatus are cultivated on these substrates compared to other processing-based residues $[42,51,55]$.

Results reported in Table 4 show that by-products generated by the olive-oil industry have been widely studied by many authors for the cultivation of edible mushrooms $[42,49,65]$, showing the highest values of biological efficiency both for P. eryngii and P. ostreatus [49]. However, these by-products gave better results by adding cereals straw, which, besides improving the structure of the growth substrate, increases the cellulose/lignin value, as can be observed by data reported in Table 4 [49,65]. It is worth mentioning that in the work of Zervakis, et al. [49] the $\mathrm{C} / \mathrm{N}$ ratio was not correlated with mushrooms biological efficiency, because increasing supplementation of olive-oil industry by-products led to the simultaneous increase of nitrogen (and other nutrients) and toxicity of the growth substrate.

In some cases, composting the growth substrate may lead to an increase in yield and biological efficiency of mushrooms cultivation [11,102], providing more readily available nutrients [49]. This could explain, together with the lower wheat straw employed, the lower biological efficiencies reported by Mansour-Benamar, et al. [65] compared to Zervakis, et al. [49] results, when P. ostreatus is cultivated on olive-oil industry by-products ( $\mathrm{BE}<35 \%$ vs. $\mathrm{BE}>85 \%$, as reported in Table 4 ). Results reported in Table 4 also show that sawdust is another common substrate used for mushrooms cultivation $[37,42,51,64]$, alone or in combination with other food industry by-products. Sawdust, as well as wheat straw, is a good substrate for mushroom cultivation because it is a good source of lignocellulosic material and because it may improve the structure of the growth medium. According to the wood from which it is generated, sawdust may have different chemical composition, in particular regarding the contents of lignin, cellulose, and hemicellulose, as well as in the $\mathrm{C} / \mathrm{N}$ ratio, which is generally high (150-520, as reported by Philippoussis [11]). Unfortunately, the type of sawdust is not always specified in the literature. Furthermore, sawdust has a low nitrogen content ( $\mathrm{N}$ about $0.1-0.2 \%$, as reported by Philippoussis [11]) hence, it is generally supplemented with another nitrogen source. Data reported by Hoa, et al. [37] in Table 4 confirmed that sawdust alone gave worst results than sawdust in combination with other processing-based residues in P. ostreatus and P. cystidious cultivation, due to the fact that supplementation with sugarcane bagasse or corncob increase the nitrogen content, 
thus reducing the $\mathrm{C} / \mathrm{N}$ ratio of the growth substrates. These results were not in agreement with those reported by Buah, et al. [64], who, however, did not report the composition of the growth substrates, thus making the comparison of the results impossible.

According to the data reported by Philippoussis [11], corncob is a substrate with relatively high hemicellulose content (35.0-43.0) respect to cellulose and lignin content, together with a not very low $\mathrm{C} / \mathrm{N}$ ratio (64.2-71.6). That's why corncob achieves low biological efficiency value (see Table 4) for Pleurotus spp. cultivation, with the exception of data reported by Hoa, et al. [37]: in this work, however, corncob had a lower $\mathrm{C} / \mathrm{N}$ ratio compared to data reported in the literature by Philippoussis [11] (34.57 vs. 64.2-71.6), and its value was negatively correlated with mushroom yield.

Some substrates (jatropha cake, peapod, and cauliflower leaves) have proven to be not suitable for mushroom growth $(\mathrm{BE}=0)$, as reported in Tables 2 and 4, probably due to their hold large amount of water $[48,55]$, which causes a lack of proper aeration and thus prevents mycelia development. However, the addition of nitrogen sources with lower water holding capacity, such as cereal straw, may allow mushroom fructification [48], also reaching very satisfying biological efficiencies (BE $>90 \%$, as reported in Table 2).

Apart from nutrition, there are many other factors that may influence mushroom cultivation: temperature, gaseous environment, water activity, light, and $\mathrm{pH}$ are in fact determining factors in regulating mycelia growth and fruiting of Basidiomycota [11], but very often this information is lacking in the scientific literature. P. ostreatus fructification, for example, is light-dependent $[11,65]$, and insufficient light during mushroom development can lead to long stalk, small-cap and low yield [102]. Also $\mathrm{pH}$ plays an important role since it is related to the contamination by molds: a $\mathrm{pH}$ value from 5 to 6 , which is favorable for P. ostreatus growth, is in fact also beneficial for the development of Trichoderma [65]. In order to avoid mold contamination, $\mathrm{pH}$ values over or equal to 7.5 are recommended for Pleurotus spp. cultivation, by limestone addition to the growth substrate [118]. Furthermore, in Pleurotus spp. cultivation the substrate with the grain spawn (inoculum) usually requires to be kept in a dark room at about $25^{\circ} \mathrm{C}$ with $80 \%$ humidity, while fructification generally occurs at temperature values of about $15^{\circ} \mathrm{C}[11,65]$.

\section{Conclusions}

Pleurotus genus is among the most cultivated mushrooms in the world, is characterized by very simple cultivation and high nutritional value. They are also well known for the ability to degrade lignocellulose, therefore, many different agri-food wastes have been used as growth substrates for Pleurotus spp. cultivation, since they are mainly composed of lignocellulosic material. In this way, low-value wastes, primarily produced through the activities of the agricultural and food-processing industries, can be converted into new resources to produce added-value food items.

The scientific works discussed in this review show the versatility of Pleurotus spp. of growing on a wide range of lignocellulosic materials. Depending on the local availability of agricultural and food industry residues, different substrates can be used in each region worldwide. However, since the substrates play the important role of supporting the growth, the development and the fruiting of mushrooms, the choice of the most suitable waste material as growth substrate to obtain maximum yield is very crucial for mushroom farmers.

The different results reported, both in terms of production parameters and chemical composition of mushrooms, are certainly affected by different factors: the species cultivated, the strain employed, the characteristics of the substrate (in terms of $\mathrm{C} / \mathrm{N}$ ratio, mineral content, water retention capacity, bioavailability of nutrients, etc.) and so on. Since the $\mathrm{C} / \mathrm{N}$ ratio plays an important role in the spawn running and the growth of the fruit body, nitrogen supplementation is an important factor for mushrooms cultivation: for this reason, the low protein contents of the lignocellulosic materials used as substrates are generally supplied with other nitrogen sources. Moreover, it is worthwhile highlighting that the differences in the results of the chemical composition of mushrooms may be due to a lack of official analytical methods. The protein content can be a clear example of this statement 
due to the converting factor employed $(\mathrm{F}=4.38$ or $\mathrm{F}=6.25)$ in the Kjeldhal method, similarly, the fiber and carbohydrates values can be deeply affected by the analytical methods used.

In any case, Pleurotus spp. have been proven to be a useful tool to upgrade and valorize some agricultural wastes: thanks to its preferential degradation of lignin and after solid-state fermentation by Pleurotus, in fact, many agricultural wastes (cereal straw and husk) result in better animal feed.

The strong oxidative activity of the Pleurotus spp. ligninolytic enzymes have also revealed a low-cost bioremediation process: in some agri-food industry residues, in fact, Pleurotus spp. are able to decrease the wastes phytotoxicity related to the presence of toxic compounds (phenols, tannins, caffeine, etc.). Furthermore, the use of food industry residues (e.g., olive mill wastes) in the growth substrate of edible mushrooms is a clear example of biotechnological application with the double result of decreasing the environmental impact of toxic wastes and producing mushrooms with high added value (increase in glucan content). The disposal of many agri-food wastes, in fact, is rather difficult, due to their inadequate biological stability, potentially pathogenic nature, potential for rapid autoxidation, high level of enzymatic activity, etc.

Although these results are encouraging, most of them come from a laboratory, or semi-pilot-scale experiments. Lab-scale data, in fact, frequently result in a much higher impact when compared with commercially available data, due to the difference in the process/system behavior when transferring results from lab-scale to pilot and industrial scale (for example, reliability of lab equipment at larger scales could be a serious problem). Therefore, a scenario analysis is needed, and the choice of the best model for scaling-up procedure becomes a critical point to minimize time, capital cost and process risks. However, it's worthwhile mentioning that innovations in the industrial processes have to be firstly developed at laboratory and pilot scale. Validation of products and processes on an industrial scale, in fact, is less thorough than laboratory and pilot-scale testing: smaller batch sizes, for example, allow more critical parameters to be assessed, thus resulting in a better understanding of the process. Lab experiments results are therefore preliminary before starting an innovation process at industrial scale.

However, many scientific works are lacking information (e.g., characteristics of the growth substrates for mushroom cultivation or the strain employed) which prevent the comparison of the different results. Therefore, further studies and harmonized procedures are needed to really evaluate the use of agri-food wastes for mushroom cultivation on an industrial scale.

Author Contributions: Conceptualization, M.R. and P.M.; Writing—Review \& Editing, M.R. and P.M.; Supervision, M.R. and P.M.

Funding: This research received no external funding.

Conflicts of Interest: The authors declare that they have no conflict of interest.

\section{References}

1. Garg, V.K.; Suthar, S.; Yadav, A. Management of food industry waste employing vermicomposting technology. Bioresour. Technol. 2012, 126, 437-443. [CrossRef] [PubMed]

2. The Economist Intelligence Unit, Barilla Centre For Food and Nutrition. Food Sustainability Index. Available online: http://foodsustainability.eiu.com/ (accessed on 11 September 2019).

3. Stenmarck, Å.; Jensen, C.; Quested, T.; Moates, G. FUSIONS-Estimates of European Food Waste Levels; IVL Swedish Environmental Research Institute: Stockholm, Sweden, 2016.

4. Mirabella, N.; Castellani, V.; Sala, S. Current options for the valorization of food manufacturing waste: A review. J. Clean. Prod. 2014, 65, 28-41. [CrossRef]

5. Ravindran, R.; Jaiswal, A.K. Exploitation of food industry waste for high-value products. Trends Biotechnol. 2016, 34, 58-69. [CrossRef] [PubMed]

6. Morales-Polo, C.; del Mar Cledera-Castro, M.; Moratilla Soria, B.Y. Reviewing the Anaerobic Digestion of Food Waste: From Waste Generation and Anaerobic Process to Its Perspectives. Appl. Sci. 2018, 8, 1804. [CrossRef]

7. Sadh, P.K.; Duhan, S.; Duhan, J.S. Agro-industrial wastes and their utilization using solid state fermentation: A review. Bioresour. Bioprocess. 2018, 5, 1. [CrossRef] 
8. Mussatto, S.I.; Ballesteros, L.F.; Martins, S.; Teixeira, J.A. Use of agro-industrial wastes in solid-state fermentation processes. In Industrial Waste; Guo, K.-Y.S.a.X., Ed.; InTech Open Access Publisher: London, UK, 2012; pp. 121-140.

9. Pandey, A. Solid-state fermentation. Biochem. Eng. J. 2003, 13, 81-84. [CrossRef]

10. Soccol, C.R.; Costa, E.S.F.d.; Letti, L.A.J.; Karp, S.G.; Woiciechowski, A.L.; Vandenberghe, L.P.d.S. Recent developments and innovations in solid state fermentation. Biotechnol. Res. Innov. 2017, 1, 52-71. [CrossRef]

11. Philippoussis, A. Production of Mushrooms Using Agro-Industrial Residues as Substrates. In Biotechnology for Agro-Industrial Residues Utilisation: Utilisation of Agro-Residues; Singh nee' Nigam, P., Pandey, A., Eds.; Springer: Dordrecht, The Netherlands, 2009; pp. 163-196. [CrossRef]

12. Baldrian, P. Fungal laccases-occurrence and properties. FEMS Microbiol. Rev. 2006, 30, 215-242. [CrossRef]

13. Hatakka, A. Lignin-modifying enzymes from selected white-rot fungi: Production and role from in lignin degradation. FEMS Microbiol. Rev. 1994, 13, 125-135. [CrossRef]

14. Pérez, J.; Muñoz-Dorado, J.; de la Rubia, T.; Martínez, J. Biodegradation and biological treatments of cellulose, hemicellulose and lignin: An overview. Int. Microbiol. 2002, 5, 53-63. [CrossRef]

15. Tengerdy, R.P.; Szakacs, G. Bioconversion of lignocellulose in solid substrate fermentation. Biochem. Eng. J. 2003, 13, 169-179. [CrossRef]

16. Sánchez, C. Lignocellulosic residues: Biodegradation and bioconversion by fungi. Biotechnology Advances 2009, 27, 185-194. [CrossRef] [PubMed]

17. Cohen, R.; Persky, L.; Hadar, Y. Biotechnological applications and potential of wood-degrading mushrooms of the genus Pleurotus. Appl. Microbiol. Biotechnol. 2002, 58, 582-594. [CrossRef] [PubMed]

18. Lankinen, P. Ligninolytic Enzymes of the Basidiomycetous Fungi Agaricus bisporus and Phlebia radiata on Lignocellulosecontaining Media. Ph.D. Dissertation, University of Helsinki, Helsinki, Finland, 2004.

19. Grimm, D.; Wösten, H.A.B. Mushroom cultivation in the circular economy. Appl. Microbiol. Biotechnol. 2018, 102, 7795-7803. [CrossRef] [PubMed]

20. FAOSTAT. Food and Agriculture Data. Available online: http://www.fao.org/faostat/en/\#home (accessed on 11 September 2019).

21. Manzi, P.; Aguzzi, A.; Vivanti, V.; Paci, M.; Pizzoferrato, L. Mushrooms as a source of functional ingredients. In Proceedings of the Euro Food Chem X European Conference on: Functional Foods. A New Challange for the Food Chemist, Budapest, Hungary, 22-24 September 1999; pp. 86-93.

22. Manzi, P.; Gambelli, L.; Marconi, S.; Vivanti, V.; Pizzoferrato, L. Nutrients in edible mushrooms: An inter-species comparative study. Food Chem. 1999, 65, 477-482. [CrossRef]

23. Kalač, P. Chemical composition and nutritional value of European species of wild growing mushrooms: A review. Food Chem. 2009, 113, 9-16. [CrossRef]

24. Kalač, P. Chemical composition and nutritional value of European species of wild growing mushrooms. In Mushrooms: Types, Properties and Nutrition; Andres, S., Baumann, N., Eds.; Nova Science Publishers, Inc.: New York, NY, USA, 2012; pp. 129-152.

25. Kalač, P. A review of chemical composition and nutritional value of wild-growing and cultivated mushrooms. J. Sci. Food Agric. 2013, 93, 209-218. [CrossRef]

26. Manzi, P.; Pizzoferrato, L. Beta-glucans in edible mushrooms. Food Chem. 2000, 68, 315-318. [CrossRef]

27. Ruthes, A.C.; Smiderle, F.R.; Iacomini, M. Mushroom heteropolysaccharides: A review on their sources, structure and biological effects. Carbohydr. Polym. 2016, 136, 358-375. [CrossRef]

28. Gargano, M.L.; Griensven, L.J.L.D.; Isikhuemhen, O.S.; Lindequist, U.; Venturella, G.; Wasser, S.P.; Zervakis, G.I. Medicinal mushrooms: Valuable biological resources of high exploitation potential. Plant Biosyst. Int. J. Deal. All Asp. Plant Biol. 2017, 151, 548-565. [CrossRef]

29. Koutrotsios, G.; Kalogeropoulos, N.; Stathopoulos, P.; Kaliora, A.C.; Zervakis, G.I. Bioactive compounds and antioxidant activity exhibit high intraspecific variability in Pleurotus ostreatus mushrooms and correlate well with cultivation performance parameters. World J. Microbiol. Biotechnol. 2017, 33, 1-14. [CrossRef]

30. Wang, S.; Bao, L.; Zhao, F.; Wang, Q.; Li, S.; Ren, J.; Li, L.; Wen, H.; Guo, L.; Liu, H. Isolation, Identification, and Bioactivity of Monoterpenoids and Sesquiterpenoids from the Mycelia of Edible Mushroom Pleurotus cornucopiae. J. Agric. Food. Chem. 2013, 61, 5122-5129. [CrossRef] [PubMed]

31. Kanagasabapathy, G.; Malek, S.N.A.; Kuppusamy, U.R.; Vikineswary, S. Chemical Composition and Antioxidant Properties of Extracts of Fresh Fruiting Bodies of Pleurotus sajor-caju (Fr.) Singer. J. Agric. Food. Chem. 2011, 59, 2618-2626. [CrossRef] [PubMed] 
32. Parola, S.; Chiodaroli, L.; Orlandi, V.; Vannini, C.; Panno, L. Lentinula edodes and Pleurotus ostreatus: Functional food with antioxidant-antimicrobial activity and an important source of vitamin D and medicinal compounds. Funct. Foods Health Dis. 2017, 7, 773-794. [CrossRef]

33. Sanchez, C. Reactive oxygen species and antioxidant properties from mushrooms. Synth. Syst. Biotechnol. 2017, 2, 13-22. [CrossRef]

34. Manzi, P.; Aguzzi, A.; Pizzoferrato, L. Nutritional value of mushrooms widely consumed in Italy. Food Chem. 2001, 73, 321-325. [CrossRef]

35. Lal, R. World crop residues production and implications of its use as a biofuel. Environ. Int. 2005, 31, 575-584. [CrossRef]

36. Cherubin, M.R.; Silva Oliveira, D.M.; Feigl, B.J.; Pimentel, L.G.; Lisboa, I.P.; Gmach, M.R.; Varanda, L.L.; Morais, M.C.; Satiro, L.S.; Popin, G.V.; et al. Crop residue harvest for bioenergy production and its implications on soil functioning and plant growth: A review. Sci. Agric. 2018, 75, 255-272. [CrossRef]

37. Hoa, H.T.; Wang, C.L.; Wang, C.H. The effects of different substrates on the growth, yield, and nutritional composition of two oyster mushrooms (Pleurotus ostreatus and Pleurotus cystidiosus). Mycobiology 2015, 43, 423-434. [CrossRef]

38. Dou, Z.; Toth, J.D.; Westendorf, M.L. Food waste for livestock feeding: Feasibility, safety, and sustainability implications. Glob. Food Secur. 2018, 17, 154-161. [CrossRef]

39. Issaka, J.; Alemawor, F.; Dzogbefia, V.P. Bioconversion impact of Pleurotus ostreatus on the value of rice and groundnut by-products as feed resources. Res. Biotechnol. 2013, 4, 24-30.

40. Nasehi, M.; Torbatinejad, N.M.; Zerehdaran, S.; Safaie, A.R. Effect of solid-state fermentation by oyster mushroom (Pleurotus florida) on nutritive value of some agro by-products. J. Appl. Anim. Res. 2017, 45, 221-226. [CrossRef]

41. Telang, S.M.; Patil, S.S.; Baig, M.M.V. Biological efficiency and nutritional value of Pleurotus sapidus cultivated on different substrates. Food Sci. Res. J. 2010, 1, 127-129.

42. Koutrotsios, G.; Mountzouris, K.C.; Chatzipavlidis, I.; Zervakis, G.I. Bioconversion of lignocellulosic residues by Agrocybe cylindracea and Pleurotus ostreatus mushroom fungi-Assessment of their effect on the final product and spent substrate properties. Food Chem. 2014, 161, 127-135. [CrossRef] [PubMed]

43. Aguilar-Rivera, N.; De Jesús-Merales, J. Edible mushroom Pleurotus ostreatus production on cellulosic biomass of sugar cane. Sugar Tech 2010, 12, 176-178. [CrossRef]

44. Gupta, A.; Sharma, S.; Saha, S.; Walia, S. Yield and nutritional content of Pleurotus sajor caju on wheat straw supplemented with raw and detoxified mahua cake. Food Chem. 2013, 141, 4231-4239. [CrossRef] [PubMed]

45. Telang, S.M.; Patil, S.S.; Baig, M.M.V. Comparative study on yield and nutritional aspect of Pleurotus eous mushroom cultivated on different substrate. Food Sci. Res. J. 2010, 1, 60-63.

46. Maynard, A.J. Methods in Food Analysis, 2nd ed.; Maynard, A.J., Ed.; Academic Press: New York, NY, USA, 1970.

47. Wankhede, D.B.; Tharanathan, R.N. Sesame (Sesamum indicum) carbohydrates. J. Agric. Food. Chem. 1976, 24, 655-659. [CrossRef]

48. Shevale, S.B.; Deshmukh, H.V. Yield performance and nutritional analysis of Pleurotus species on different agro wastes and vegetable wastes. Int. J. Plant Prot. 2016, 9, 162-167. [CrossRef]

49. Zervakis, G.I.; Koutrotsios, G.; Katsaris, P. Composted versus raw olive mill waste as substrates for the production of medicinal mushrooms: An assessment of selected cultivation and quality parameters. BioMed Res. Int. 2013, 2013, 546830. [CrossRef]

50. Koutrotsios, G.; Kalogeropoulos, N.; Kaliora, A.C.; Zervakis, G.I. Toward an Increased Functionality in Oyster (Pleurotus) Mushrooms Produced on Grape Marc or Olive Mill Wastes Serving as Sources of Bioactive Compounds. J. Agric. Food. Chem. 2018, 66, 5971-5983. [CrossRef] [PubMed]

51. Sardar, H.; Ali, M.A.; Anjum, M.A.; Nawaz, F.; Hussain, S.; Naz, S.; Karimi, S.M. Agro-industrial residues influence mineral elements accumulation and nutritional composition of king oyster mushroom (Pleurotus eryngii). Sci. Hort. 2017, 225, 327-334. [CrossRef]

52. Raja, S.; Mallesha, B.C.; Gowda, P.A. Effect of micronutrients on growth and yield of mushrooms. Mysore J. Agric. Sci. 2013, 47, 66-69.

53. Pekşen, A.; Küçükomuzlu, B. Yield potential and quality of some Pleurotus species grown in substrates containing hazelnut husk. Pak. J. Biol. Sci. 2004, 7, 768-771. 
54. Hossain, M.M. Effect of different substrates on yield of Pleurotus ostreatus mushroom. Environ. Ecol. 2018, 36, 312-315.

55. Chitamba, J.; Dube, F.; Chiota, W.M.; Handiseni, M. Evaluation of substrate productivity and market quality of oyster mushroom (Pleurotus ostreatus) grown on different substrates. Int. J. Agric. Res. 2012, 7, 100-106. [CrossRef]

56. Mane, V.P.; Patil, S.S.; Syed, A.A.; Baig, M.M. Bioconversion of low quality lignocellulosic agricultural waste into edible protein by Pleurotus sajor-caju (Fr.) Singer. J. Zhejiang Univ. Sci. B 2007, 8, 745-751. [CrossRef] [PubMed]

57. Jeznabadi, E.K.; Jafarpour, M.; Eghbalsaied, S. King oyster mushroom production using various sources of agricultural wastes in Iran. Int. J. Recycl. Org. Waste Agric. 2016, 5, 17-24. [CrossRef]

58. Kadam, K.L.; McMillan, J.D. Availability of corn stover as a sustainable feedstock for bioethanol production. Bioresour. Technol. 2003, 88, 17-25. [CrossRef]

59. Khan, S.M.; Nawaz, A.; Ali, M.A.; Ahmad, T.; Khan, N.A.; Rehman, A.U. Response of oyster mushroom on different agricultural wastes of Southern Punjab. Pak. J. Agric. Sci. 2012, 49, 127-130.

60. Mumtaz, M.S.; Khan, N.A.; Abdul, R.; Abdul, J. Production of oyster mushroom (Pleurotus pulmonarius) on different agriculture wastes combination with lemon grass (Cymbopogon citratus). Pak. J. Phytopathol. 2016, $28,71-75$.

61. Vieira, F.R.; Andrade, M.C.N. Optimization of substrate preparation for oyster mushroom (Pleurotus ostreatus) cultivation by studying different raw materials and substrate preparation conditions (composting: Phases I and II). World J. Microbiol. Biotechnol. 2016, 32, 190. [CrossRef] [PubMed]

62. Batish, D.R.; Tung, P.; Singh, H.P.; Kohli, R.K. Phytotoxicity of sunflower residues against some summer season crops. J. Agron. Crop Sci. 2002, 188, 19-24. [CrossRef]

63. Nanjappa, H.; Poonguzhalan, R.; Ramachandrappa, B. Influence of sunflower on subsequent crops. Allelopath. J. 1999, 6, 69-74.

64. Buah, J.N.; Van der Puije, G.C.; Bediako, E.A.; Abole, E.A.; Showemimo, F. The growth and yield performance of oyster mushroom (Pleurotus ostreatus) on different substrates. Biotechnology 2010, 9, 338-342. [CrossRef]

65. Mansour-Benamar, M.; Savoie, J.M.; Chavant, L. Valorization of solid olive mill wastes by cultivation of a local strain of edible mushrooms. Comptes Rendus Biol. 2013, 336, 407-415. [CrossRef] [PubMed]

66. Roig, A.; Cayuela, M.L.; Sanchez-Monedero, M.A. An overview on olive mill wastes and their valorisation methods. Waste Manag. 2006, 26, 960-969. [CrossRef] [PubMed]

67. Ntougias, S.; Bourtzis, K.; Tsiamis, G. The microbiology of olive mill wastes. BioMed Res. Int. 2013, 2013, 784591. [CrossRef] [PubMed]

68. Brozzoli, V.; Bartocci, S.; Terramoccia, S.; Contò, G.; Federici, F.; D’Annibale, A.; Petruccioli, M. Stoned olive pomace fermentation with Pleurotus species and its evaluation as a possible animal feed. Enzyme Microb. Technol. 2010, 46, 223-228. [CrossRef]

69. Koutrotsios, G.; Zervakis, G.I. Comparative examination of the olive mill wastewater biodegradation process by various wood-rot macrofungi. BioMed Res. Int. 2014, 2014, 482937. [CrossRef]

70. Ntougias, S.; Baldrian, P.; Ehaliotis, C.; Nerud, F.; Antoniou, T.; Merhautova, V.; Zervakis, G.I. Biodegradation and detoxification of olive mill wastewater by selected strains of the mushroom genera Ganoderma and Pleurotus. Chemosphere 2012, 88, 620-626. [CrossRef] [PubMed]

71. Avni, S.; Ezove, N.; Hanani, H.; Yadid, I.; Karpovsky, M.; Hayby, H.; Gover, O.; Hadar, Y.; Schwartz, B.; Danay, O. Olive mill waste enhances alpha-glucan content in the edible mushroom Pleurotus eryngii. Int. J. Mol. Sci. 2017, 18, 1564. [CrossRef] [PubMed]

72. Reverberi, M.; Di Mario, F.; Tomati, U. b-Glucan synthase induction in mushrooms grown on olive mill wastewaters. Appl. Microbiol. Biotechnol. 2004, 66, 217-225. [CrossRef] [PubMed]

73. Ruiz-Rodriguez, A.; Soler-Rivas, C.; Polonia, I.; Wichers, H.J. Effect of olive mill waste (OMW) supplementation to Oyster mushrooms substrates on the cultivation parameters and fruiting bodies quality. Int. Biodeterior. Biodegrad. 2010, 64, 638-645. [CrossRef]

74. Zacharof, M.-P. Grape Winery Waste as Feedstock for Bioconversions: Applying the Biorefinery Concept. Waste Biomass Valorization 2017, 8, 1011-1025. [CrossRef]

75. Nerantzis, E.T.; Tataridis, P. Integrated enology-utilization of winery by-products into high added value products. J. Sci. Technol. 2006, 1, 79-89. 
76. Pérez-Bibbins, B.; Torrado-Agrasar, A.; Pérez-Rodríguez, N.; Aguilar-Uscanga, M.G.; Domínguez, J.M. Evaluation of the liquid, solid and total fractions of beer, cider and wine lees as economic nutrient for xylitol production. J. Chem. Technol. Biotechnol. 2015, 90, 1027-1039. [CrossRef]

77. Petre, M.; Teodorescu, A.; Giosanu, D.; Bejan, C. Enhanced cultivation of mushrooms on organic wastes from wine-making industry. J. Environ. Prot. Ecol. 2012, 13, 1488-1492.

78. Mussatto, S.I.; Dragone, G.; Roberto, I.C. Brewers' spent grain: Generation, characteristics and potential applications. J. Cerral Sci. 2006, 43, 1-14. [CrossRef]

79. Wang, D.; Sakoda, A.; Suzuki, M. Biological efficiency and nutritional value of Pleurotus ostreatus cultivated on spent beer grain. Bioresour. Technol. 2001, 78, 293-300. [CrossRef]

80. Gregori, A.; Svagelj, M.; Pahor, B.; Berovic, M.; Pohleven, F. The use of spent brewery grains for Pleurotus ostreatus cultivation and enzyme production. New Biotechnol. 2008, 25, 157-161. [CrossRef] [PubMed]

81. Prabhu, S.R.; Thomas, G.V. Biological conversion of coir pith into a value-added organic resource and its application in Agri-Horticulture: Current status, prospect and perspective. J. Plant. Crops 2002, 30, 1-17.

82. Pandey, A.; Soccol, C.R.; Nigam, P.; Brand, D.; Mohan, R.; Roussos, S. Biotechnological potential of coffee pulp and coffee husk for bioprocesses. Biochem. Eng. J. 2000, 6, 153-162. [CrossRef]

83. Parani, K.; Eyini, M. Biodegradation of coffee pulp waste by different fungal associations. Bio. Disc. 2012, 3, 222-228.

84. García, O.; Bermúdez, S.; Gaime, P.; Rodríguez, P.; Aguilera, R.; Morris, Q. Production of Pleurotus's ligninolityc enzymes on coffee pulp by solid state fermentation. In Proceedings of the 7th International Conference on Mushroom Biology and Mushroom Products, Arcachon, France, 4-7 October 2011; pp. 144-149.

85. Da Luz, J.M.R.; Nunes, M.D.; Paes, S.A.; Torres, D.P.; Silva, M.C.S.; Kasuya, M.C.M. Lignocellulolytic enzyme production of Pleurotus ostreatus growth in agroindustrial wastes. Braz. J. Microbiol. 2012, 43, 1508-1515. [CrossRef] [PubMed]

86. Hoa, H.T.; Wang, C.H.; Tam, N.V.; Wang, C.L. Effects of substrates and drying methods on antioxidant compound and antioxidant activity of fruiting body extracts of two oyster mushrooms (Pleurotus ostreatus and Pleurotus cystidiosus). Int. Food Res. J. 2017, 24, 1998-2008.

87. Wang, C.Q.; Wu, S.J.; Wei, S.Y.; Qin, X.J.; Chen, L.X.; Yang, C.; Chen, X.F.; Wu, X.J. Screening for cultivation medium formula of Pleurotus pulmonarius with eucalyptus sawdust as main material. J. South. Agric. 2016, 47, 624-628.

88. Li, Z.; Pan, H.; Li, Y.; Yu, H.; Wang, R.; Zhou, F.; Tan, Q.; Guo, Q. Effects of corncob particle size on the mycelium growth and yield of Pleurotus eryngii in factory production. Acta Agric. Shanghai 2011, 27, 46-48.

89. Satyanarayana, K.G.; Arizaga, G.G.C.; Wypych, F. Biodegradable composites based on lignocellulosic fibers-An overview. Prog. Polym. Sci. 2009, 34, 982-1021. [CrossRef]

90. Saha, B.C. Hemicellulose bioconversion. J. Ind. Microbiol. Biotechnol. 2003, 30, 279-291. [CrossRef]

91. Hofsetz, K.; Silva, M.A. Brazilian sugarcane bagasse: Energy and non-energy consumption. Biomass Bioenergy 2012, 46, 564-573. [CrossRef]

92. Cardona, C.A.; Quintero, J.A.; Paz, I.C. Production of bioethanol from sugarcane bagasse: Status and perspectives. Bioresour. Technol. 2010, 101, 4754-4766. [CrossRef] [PubMed]

93. Camassola, M.; Dillon, A.J.P. Biological pretreatment of sugar cane bagasse for the production of cellulases and xylanases by Penicillium echinulatum. Ind. Crops Prod. 2009, 29, 642-647. [CrossRef]

94. Dong, X.Q.; Yang, J.S.; Zhu, N.; Wang, E.T.; Yuan, H.L. Sugarcane bagasse degradation and characterization of three white-rot fungi. Bioresour. Technol. 2013, 131, 443-451. [CrossRef] [PubMed]

95. Anyakorah, C.I.; Dike, E.N. Comparison of sawdust and rice husk as casing materials for Pleurotus pulmonarius propagation on cassava peel substrate. Agric. Biol. J. N. Am. 2012, 4, 552-554. [CrossRef]

96. Dairo, A.; Ogunlade, S.W.; Oluwasola, T.A. Proximate composition and amino acid profile of rice husk biodegraded with Pleurotus ostreatus for different periods. Afr. J. Food Agric. Nutr. Dev. 2017, 17, 12243-12255. [CrossRef]

97. Uzuner, S.; Sharma-Shivappa, R.R.; Cekmecelioglu, D. Bioconversion of Alkali Pretreated Hazelnut Shells to Fermentable Sugars for Generation of High Value Products. Waste Biomass Valorization 2017, 8, 407-416. [CrossRef]

98. Çöpür, Y.; Güler, C.; Akgül, M.; Taşçıŏlu, C. Some chemical properties of hazelnut husk and its suitability for particleboard production. Build. Environ. 2007, 42, 2568-2572. [CrossRef] 
99. Esposito, T.; Sansone, F.; Franceschelli, S.; Del Gaudio, P.; Picerno, P.; Aquino, R.P.; Mencherini, T. Hazelnut (Corylus avellana L.) shells extract: Phenolic composition, antioxidant effect and cytotoxic activity on human cancer cell lines. Int. J. Mol. Sci. 2017, 18, 392. [CrossRef]

100. Yuan, B.; Lu, M.; Eskridge, K.M.; Isom, L.D.; Hanna, M.A. Extraction, identification, and quantification of antioxidant phenolics from hazelnut (Corylus avellana L.) shells. Food Chem. 2018, 244, 7-15. [CrossRef]

101. Zervakis, G.I.; Koutrotsios, G. Solid-State Fermentation of Plant Residues and Agro-industrial Wastes for the Production of Medicinal Mushrooms. In Medicinal Plants and Fungi: Recent Advances in Research and Development; Agrawal, D.C., Tsay, H.-S., Shyur, L.-F., Wu, Y.-C., Wang, S.-Y., Eds.; Springer: Singapore, 2017; pp. 365-396. [CrossRef]

102. Yildiz, S.; Yildiz, Ü.C.; Gezer, E.D.; Temiz, A. Some lignocellulosic wastes used as raw material in cultivation of the Pleurotus ostreatus culture mushroom. Process Biochem. 2002, 38, 301-306. [CrossRef]

103. Mandeel, Q.A.; Al-Laith, A.A.; Mohamed, S.A. Cultivation of oyster mushrooms (Pleurotus spp.) on various lignocellulosic wastes. World J. Microbiol. Biotechnol. 2005, 21, 601-607. [CrossRef]

104. Lavelli, V.; Proserpio, C.; Gallotti, F.; Laureati, M.; Pagliarini, E. Circular reuse of bio-resources: The role of Pleurotus spp. in the development of functional foods. Food Funct. 2018, 9, 1353-1372. [CrossRef]

105. Crisan, E.V.; Sands, A. Nutrtional value. In The Biology and Cultivation of Edible Mushrooms; Chang, S.T., Hayes, W.A., Eds.; Academic Press: New York, NY, USA, 1978.

106. Bonatti, M.; Karnopp, P.; Soares, H.M.; Furlan, S.A. Evaluation of Pleurotus ostreatus and Pleurotus sajor-caju nutritional characteristics when cultivated in different lignocellulosic wastes. Food Chem. 2004, 88, 425-428. [CrossRef]

107. Shashirekha, M.N.; Rajarathnam, S.; Bano, Z. Effects of supplementing rice straw growth substrate with cotton seeds on the analytical characteristics of the mushroom, Pleurotus florida (Block \& Tsao). Food Chem. 2005, 92, 255-259.

108. Pomeranz, Y.; Meloan, C.E. Food Analysis Theory and Practice; Springer: Medford, MA, USA, 2000; pp. XIV, 778.

109. Nikkarinen, M.; Mertanen, E. Impact of geological origin on trace element composition of edible mushrooms. J. Food Compost. Anal. 2004, 17, 301-310. [CrossRef]

110. Mikiashvili, N.; Wasser, S.P.; Nevo, E.; Elisashvili, V. Effects of carbon and nitrogen sources on Pleurotus ostreatus ligninolytic enzyme activity. World J. Microbiol. Biotechnol. 2006, 22, 999-1002. [CrossRef]

111. Nunes, M.D.; Luz, J.M.R.d.; Paes, S.A.; Ribeiro, J.J.O.; Silva, M.d.C.S.d.; Kasuya, M.C.M. Nitrogen supplementation on the productivity and the chemical composition of oyster mushroom. J. Food Res. 2012, 1, 113-119. [CrossRef]

112. Kurt, S.; Buyukalaca, S. Yield performances and changes in enzyme activities of Pleurotus spp. (P. ostreatus and P. sajor-caju) cultivated on different agricultural wastes. Bioresour. Technol. 2010, 101, 3164-3169. [CrossRef]

113. Obodai, M.; Cleland-Okine, J.; Vowotor, K.A. Comparative study on the growth and yield of Pleurotus ostreatus mushroom on different lignocellulosic by-products. J. Ind. Microbiol. Biotechnol. 2003, 30, 146-149. [CrossRef] [PubMed]

114. Claye, S.S.; Idouraine, A.; Weber, C.W. Extraction and fractionation of insoluble fiber from five fiber sources. Food Chem. 1996, 57, 305-310. [CrossRef]

115. Khan, T.S.; Umarah, M. Wheat straw: A pragmatic overview. Curr. Res. J. Biol. Sci. 2012, 4, 673-675.

116. Knop, D.; Yarden, O.; Hadar, Y. The ligninolytic peroxidases in the genus Pleurotus: Divergence in activities, expression, and potential applications. Appl. Microbiol. Biotechnol. 2015, 99, 1025-1038. [CrossRef] [PubMed]

117. Patra, A.K.; Pani, B.K. Evaluation of banana leaf as a new alternative substrate to paddy straw for oyster mushroom cultivation. J. Phytol. Res. 1995, 8, 145-148.

118. Royse, D.J. Specialty mushrooms. In Mushroom Fact Sheet; Laboratory, M.S., Ed.; Penn State University: State College, PA, USA, 2004.

(C) 2019 by the authors. Licensee MDPI, Basel, Switzerland. This article is an open access article distributed under the terms and conditions of the Creative Commons Attribution (CC BY) license (http://creativecommons.org/licenses/by/4.0/). 